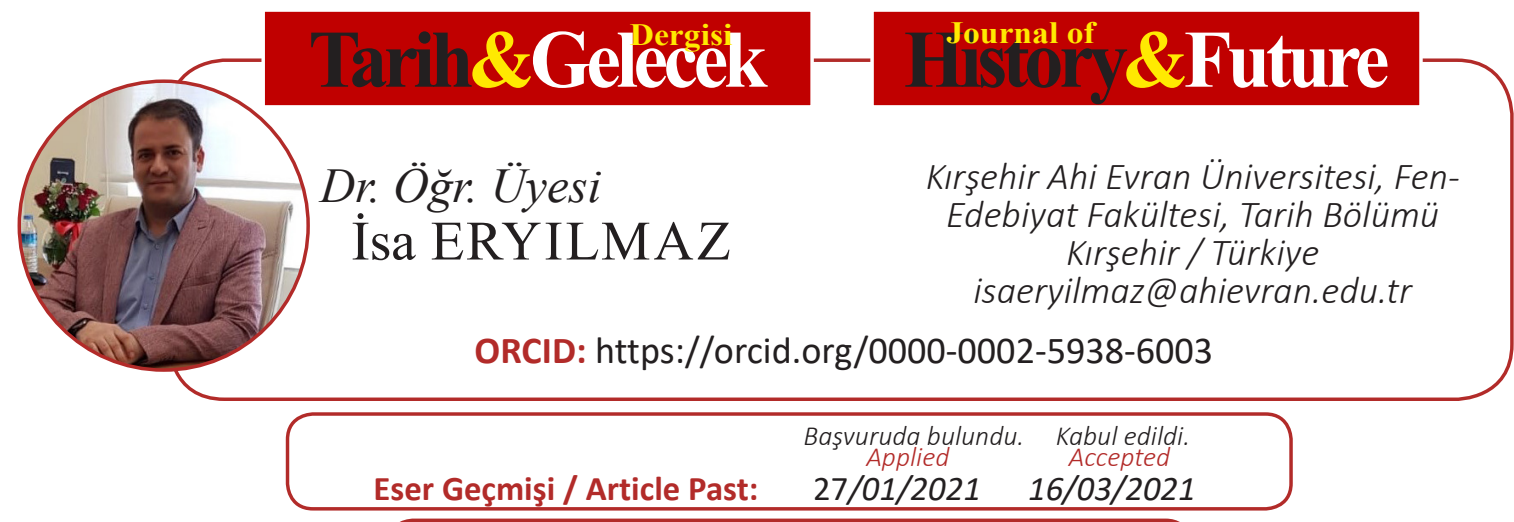

Araştırma Makalesi

DOI: http://dx.doi.org/10.21551/jhf.869257

Research Paper

Orjinal Makale / Orginal Paper

\title{
Türkistan Coğrafyası ve Jeopolitiği
}

\section{$\ddot{O} \mathbf{z}$}

\section{Turkistan Geography and Geopolitics}

XX. yüzyılın başlarından itibaren ideolojik sâiklerle Orta Asya olarak adlandırılan Türkistan, Batı kaynaklarında umumîyetle işgalci ülkelere göre isimlendirilmekte, yani Batı Türkistan'a Sovyet Türkistan'1, Doğu Türkistan'a Çin Türkistan'1 ve Güney Türkistan'a da Afgan Türkistan'ı denilmektedir. Geniş bozkırları, yer yer münbit arazileri, dağ ve nehirleri ihtiva eden Türkistan coğrafyası, tarih boyunca pek çok medeniyete ev sahipliği yapmıştır. Diğer taraftan Çin'den Ön Asya’ya açılan tarihi İpek Yolu dışında kuzeyde yer alan askerî yollar Türkistan jeopolitiğinde belirleyici olmuştur. O sebeple Türkistan hâkimiyetinde kalp-gâh durumundaki kilit noktaların bilincinde olan Türk devlet adamları iktidar mücadelelerinde bu önemli şah damarlarını ellerinde tutmaya çalışmışlardır. Bu sayede Hun, Gök-Türk (Kök-Türk), Gazneli, Karahanlı ve Selçuklu gibi Türk devletleri uzak bölgelere hükmedebilmişlerdir. Çingiz ve sonrasında da gördüğümüz söz konusu düşünceye sahip muhtelif hakimiyetler siyasî ve iktisadî ihtiyaçlara cevap verebilmek için bölgenin jeopolitiğini her dönemde göz önünde bulundurmuşlar ve gerekli tedbirleri almışlardır. Türkistan'a hâkim olma düşüncesiyle alınan bu tedbirler batıda Buhara, Merv, Semerkant, Taşkent ve Harezm; doğuda Kaşgar, Yarkent, Hotan ve Turfan gibi şehirlerin önemini artırdığı gibi buraların ticaret ve kültür merkezleri haline gelmesine de zemin hazırlamıştır.

Anahtar kelimeler: Jeopolitik, Türkistan, Ön Asya, Kalp-gâh, İpek Yolu.

\section{Abstract}

Turkestan which has been called Central Asia for ideological motives since the beginning of the century, is generally named according to the invading countries in Western sources, that is, West Turkestan is called Soviet Turkestan, East Turkestan is called China Turkestan and South Turkistan is Afghan Turkestan. The geography of Turkestan, which includes vast steppes, occasionally fertile lands, mountains and rivers, has hosted many civilizations throughout history. On the other hand, apart from the historical Silk Road from China to Asia Minor, the military roads in the north have been determinant in Turkestan geopolitics. For this reason, Turkish statesmen, who are aware of the key points in the state

ATIF: ERYILMAZ, İsa, "Türkistan Coğrafyası ve Jeopolitiği”, Tarih ve Gelecek Dergisi, 7/1 (Mart 2021), s. (315-333) 
of heartland under the domination of Turkestan, have tried to keep these important jugular veins in their hands in their power struggles. In this way, Turkish states such as Hun, GokTurk, Ghaznavid, Karakhanid and Seljuk were able to dominate distant regions. Chinggis and various rulers with the aforementioned idea, which we saw afterwards, took into account the geopolitics of the region in every period and took the necessary measures in order to respond to the political and economic needs. These measures taken with the idea of dominating Turkestan in the west, Bukhara, Merv, Samarkand, Tashkent and Khwarezm; In the east, it has increased the importance of cities such as Kashgar, Yarkant, Hotan and Turfan, as well as paving the way for these to become trade and cultural centers.

Keywords: Geopolitics, Turkestan, Front Asia, Heartland, Silk Road.

\section{Giriş}

Yeryüzündeki kıtaların en büyüğ $\ddot{u}^{1}$ olan Asya'nın² merkezi bölümündeki bozkırları ihtiva eden Türkistan, ${ }^{3}$ kıtanın kalp-gâhı durumunda olup ${ }^{4}$ kuzeyde bugünkü Kazakistan bozkırları ve Sibirya'nın güneyi, güneyde Himalaya silsilesi, Hindukuş ve Afganistan, ${ }^{5}$ batıda Hazar Denizi ve doğuda da Kadırgan ${ }^{6}$ Dağları ile çevrelenir. ${ }^{7}$

1 Asya yeryüzündeki kıtaların en büyüğüdür. Ekvatorun kuzeyinde 80. paralele kadar uzanır ve güneyde de ekvatora oldukça yaklaşır. Bu nedenle üç kuşağı yani, çok soğuk, 1lıman ve sıcak ya da kurak iklimlerin bulunduğu kuşağı ihtiva eder. Asya, yaklaşı 17000 millik alanı ya da daha doğrucası dünya yüzeyinin üçte birini oluşturur. Yani, Kuzey Amerika'dan iki, Avrupa'dan da beş kat daha büyüktür. Bkz. C. D. Tenney, Geography of Asia, London 1904, s.1.

2 Asya ismi, en erken Herodot zamanlarına kadar götürülmekte [J.A. Cramer, A Geographical and Historical Description of Asia Minor, Oxford 1961, s.1.] ve Avrupa'nın doğusundaki kıtaya verilen ad olarak temayüz etmektedir. Bu hususta Fernand Grenard da "Daha bundan yirmi dört asır kadar önce, Herodot, Avrupa'yı Asya'nın karşısına çıkarmış, kısa fakat doğru notlarla iki kıta arasındaki siyasi ve manevi farkları gösterdiği gibi coğrafi hudutları da tespit etmişti.” [F. Grenard, Asya'nın Yükselişi ve Düşüşü, (nşr. O. Yüksel), İstanbul 1992, s. 13.] derken bunu teyit etmiştir. Coğrafyacılar, en eski kıtalardan birisi olan Asya'yı beş tabii bölgeye ayırırlar. Coğrafya bilginlerinin coğrafyacı gözüyle çizdikleri bu sınır çizgilerinin yalnız coğrafya bakımından birlik gösteren, birbirine bağlı araziyi değil, aynı zamanda Asya’nın tarihi ve medeni birliklerinin yayıldıkları alanları da adeta ölçülü bir tamlıkla göstermeleri ilk bakışta belki biraz şaşırtıcıdır. Hakikatte bu tabii bir şeydir. Zira toprakla insan birbirinden ayrılamaz ve coğrafi şartlar ise insanın tarihi yolunu, hayati hususiyetini adeta kader gibi tayin ederler. Bkz. L. Ligeti, Bilinmeyen İç Asya, (nşr. S. Karatay), Ankara 1986, s. 13.

3 Türkistan kelimesi lügatte, Türkçe-Farsça birleşik isim olup, Türklerin anayurdu olan ve Taşkent, Hive, Fergana, Semerkand, Buhara ve Kırgız şehirlerini içine büyük bölge olarak geçmektedir. Bkz. F. Devellioğlu, Osmanlıca-Türkçe Ansiklopedik Lügat, Ankara 2003, s. 1343.

4 Genel olarak bkz. F.H. Skrine- Ross, E. Denison., The Heart of Asia (A History of Russian Turkestan and the Central Asian Khanates from the Earliest Times), London 1899, s. 3.

5 Bering Boğazı'ndan Babülmendep'e kadar uzanan yaklaşık 7.500 millik bir sahada yer alan Asya kıtasının güney sınırı dünya çevresinin takriben üçte birini oluşturur. Asya’nın kuzey sınırı coğrafi bakımdan bir süreklilik arz ederken, güney sınırı yüksek, sarp ve çok kısıtlı geçitlerden oluşan dağ silsilelerini ihtiva eder. Bunlardan birisi olan Himalaya silsilesi, Asya’nın başlıca dağ dizilerinden birini teşkil eder ve Afganistan'ın da içinde yer aldığı Hindukuş ve Pamir yaylasından farklılık arz eder ve oradan adeta bir insan parmağı gibi doğuya uzanır. Bkz. Tenney, s. 1.

6 Bu dağ isminin Kingan Dağı'nın muadili olarak kullanılması hakkında mesela bkz., M. Ergin, Orhun Abideleri, İstanbul 2006, s. 9, 17, 33, 41.

$7 \quad$ A.Z.V. Togan, Umumî Türk Tarihi'ne Giriş, İstanbul 1981, s. 44. 
Her ne kadar Taberi'nin kayıtlarına göre ${ }^{8}$ Türkistan batıda Hazar Denizi ${ }^{9}$ ve doğuda daha kesin çizgilerle olmak üzere Sir Derya (Seyhun Nehri) ve Hindukuş Dağları ile sınırlanmakta ise de ${ }^{10}$ Türk ve zaman zaman da Moğol göçebelerin yaşadıkları bölgeleri göz önüne alarak ünlü Macar âlimi Ligeti, bu ülkenin batısını Hazar Denizi ve doğusunu da Kadırgan Dağları'ndan doksan derecelik bir açıyla güneye yönelttiği ve itibarî bir coğrafi hat boyunca Tibet Platosu'na kadar çizdiği hudutla sınırlar. ${ }^{11}$

İslam ülkeleri ile Çin arasında uzanan, Türk ve Moğol göçebelerinin yaşadığı bölge olarak tanınan Türkistan, ${ }^{12}$ Macarlar tarafindan İç Asya olarak adlandırılmaktayken ${ }^{13}$ günümüzde Orta Asya olarak bilinmekte ${ }^{14}$ ve bu sahanın münbit ve mahsûldar bölgelerini teşkil eden Batı - Doğu Türkistan olarak iki ana kısma ayrılmaktadır. ${ }^{15}$ Batı kaynaklarında ise Türkistan işgalci ülkelere göre

8 Taberi’nin kayıtlarına göre Türkistan coğrafyasının kesin sınırlarını belirlemek oldukça güçtür. Ancak, Maveraünnehir'in Türk memleketlerinin içerisi olarak adlandırılması, Türk ülkesinin Ceyhun ve Seyhun arasında kalan bölgeden çok daha geniş bir coğrafyayı kapsadığı, Hazar'ın da bu ülkenin tabii batı sınırını teşkil ettiği anlaşılmaktadır. Bkz., Taberî, Milletler ve Hükümdarlar Tarihi I, (nşr. Z. Kadirî-A. Temir), İstanbul 1992, s. 1022.

9 Üzerinde yerleşim yerleri ve yurtlar bulunan bu deniz, Bab el-Ebvâb, Hazar, Cîl, Deylem, Cürcan ve Taberistan denizi adıyla da bilinir. Çevresinde çeşitli Türk kabileleri yaşar ve bir tarafı Horasan yönünden Harezm’e birleşir. Bkz. Mesudî, Murûc ez-Zeheb (Altın Bozkırlar), (nşr. A. Batur), İstanbul 2004, s. 37.

10 H. Skrine- Ross, E. Denison., s. 3 vd.

11 Bkz. Ligeti, s. 15.

12 Türk-Moğol göçebeleri, eskiden beri Doğu ve Batı Asya'daki kültür mıntıkalarının kuzeyinde uzanan bölgelerle Doğu Avrupa steplerini işgal eden kavimler arasında yer alırlar. Atlı göçebe bozkır kültürünün temsilcileri olarak Türklerin yaşadıkları at yetiştirmeye ve genel olarak hayvan beslemeye elverişli bölgenin doğu sınırı, Mançurya'da Kadırgan sıra dağları, batı sınırı ise Macaristan stepleridir (Geniş bilgi için bkz. W. Barthold, Türk-Moğol Ulusları Tarihi, (nşr. H. Eren), Ankara 2006, s.1 vd.). Yukarıda bahsi geçen kabilelerden olan Saka'lar, Yüe-çi'ler ve Kuşan'lar, bunların yerleri meselesi ve göçleri hakkında etraflı bilgi için bkz. B. Ögel, "Eski Orta Asya Kabileleri Hakkında Araştırmalar I: Yüe-çi'ler" Ankara Üniversitesi Dil ve Tarih-Coğrafya Fakültesi Dergisi, XV/1-3, (Mart-Haziran-Eylül 1957), s. 247 vd.

13 D. Sinor, “İç Asya Kavramı”, Erken İç Asya Tarihi, (nşr. D. Sinor), İstanbul 2000, s. 13.

14 Türk kelimesinin Farsça "istan” ekiyle birleşmesinden oluşan ve Türklerin ülkesi manasını ifade eden bu kelimenin anlattığı coğrafi kavram itibarıyla, sınırlarının ve kapsamının belirlenmesi durumu, bugün özellikle Rus basınında çok fazla suistimallere uğramaktadır. Orta Asya'daki yerli Türkleri birleştirebilecek bir ülkü olabileceğini belirledikleri için "Türk", "Türkistan” kelimelerine karşı Ruslar, özellikle Bolşevizm döneminde, aşırı bir duyarlılık göstermektedirler. 16 Haziran 1924'te "Turtsik"in (yani Türkistan'da Bolşevik Merkezi İdaresi) kararıyla "Türkistan” ve "Türk Respublika" kelimeleri ortadan kaldırılarak yerine, bütün dünya ilim âleminde daha çok Doğu Türkistan, Moğolistan ve Tibet bölgeleri için kullanılan "Orta Asya" kelimesi geçirildi ve Siriderya'nın aşağı kısımları, Aral Gölü ve Mankışlak hariç tutularak, "Rus Türkistan'ı” karşılığında kullanılmaya başladı. Bkz. A.Z. Velidî, “Türkistan İsmi Sınırları ve Yüzölçümü Hakkında", Türkistan’ın Bağımsızlığına Hizmet Eden "Yeni Türkistan'dan Seçmeler (1927-1931)”, İstanbul 2005, s. 25.

15 Türkistan, Çin'e tâbi olan doğu yarısı Doğu Türkistan ve Rusya'ya tâbi olan batı yarısı Batı Türkistan diye ikiye bölünür. Doğu Türkistan, $1.503 .563 \mathrm{~km}$ kare olup bunun $1.118 .713 \mathrm{~km}$ karelik bölümü Tarım havzasından ibaret olan Kaşgarya'ya, $384.850 \mathrm{~km}$ karelik sahası da "İle" vilayeti ile Çungarya'ya aittir. Batı Türkistan ise, 3.836 .503 km kare olup bunun 1.979 .816 km karesi Türkistan Umumî Valiliğini teşkil eden vilayetlerle sabık Buhara ve Hive hanlıklarına, $1.856 .687 \mathrm{~km}$ karesi de sabık Rus idari taksimatında Sahra Vilayetleri denilen Kazakistan'a aittir. Bkz. A.Z.V. Togan, Bugünkü Türkili (Türkistan) ve Yakın Tarihi I (Batı ve Kuzey Türkistan), İstanbul 1981, s. 1. 
isimlendirilmekte, yani Batı Türkistan'a Sovyet Türkistan'1, ${ }^{16}$ Doğu Türkistan'a Çin Türkistan' $1{ }^{17}$ ve Güney Türkistan'a da Afgan Türkistan'1 denilmektedir. ${ }^{18}$

Coğrafî̀ bakımdan Avrasya (Eurasia)'nın'19 da bir kısmını ihtiva eden Türkistan'ın en önemli dağ silsilelerinden birisi olan Tanrı (Tiyen-Şan) ${ }^{20}$ ve Altay Dağlar1 ${ }^{21}$ adeta kopuk bir zincir görünümünde olup bu ikisi arasında Çungarya kapısı adında bir geçit bulunmaktadır. ${ }^{22} \mathrm{Bu}$ dağ güzergâhlarını da içine alan Türkistan'ın sınırı Ural Dağları'ndan başlar, doğuya doğru Akmola Yaylası'ndan geçer, Altayların kuzey eteklerini takip ederek biraz kuzeye kıvrılır ve Sibirya'nın güney hattını takip ederek doğuda Büyük Kadırgan Dağı'na ulaşır. ${ }^{23}$ Buradan güneye inerek

16 En eski zamanlardan beri Rusya, Türkistan özellikle de Ural-Altay bölgesi ve ırkları ile temas içerisinde olmuştur. Bu husus özellikle Rusya'nın coğrafi pozisyonuna yani Türkistan coğrafyası ile olan yakınlığına atfedilebilir. Fakat bu temas her zaman dostça olmamış ve özelikle de dini, siyasi ve sosyal ilişkilerde zaman zaman uyuşmazlıklar yaşanmıştır. A. Vambéry, Western Culture in Eastern Lands, London 1906, S. $7 \mathrm{vd}$.

17 Doğu Türkistan olarak bilinen Çin Türkistan'1, 1877'den beri Çin tarafından Yakub Bey'in haleflerine karşı Tso-Tsung-tang’ın büyük kampanyaları sonucu resmi olarak bu şekilde adlandırıla gelmiştir. Bu isim, bölgeye Tanrı dağları yakınındaki "İli” gibi yalnızca yöresel isimlerle hitap eden yerleşikler tarafından pek tercih edilmemektedir. Takriben yarım milyon millik bir alanı kapsayan ülke, kuzeyde Moğolistan ve güneyde de Tibet arasına adeta sıkışmış gibidir. Batısı Pamirler tarafından kapatılırken, doğusu Çin'e açılır (Bkz. A. Little, The Far East, Oxford 1905, s. 117). Bu bahse misal olarak Çin Türkistan'ın ve bazı şehirleri hakkında geniş bilgi için bkz. P.W. Church, Chinese Turkestan, London 1901, s. 1 vd.

18 A. Yiğit, Türk Ülkeleri ve Türklerin Yaşadıkları Bölgelerin Coğrafyası, Elâzığ 2000, s. 75.

19 Çağımızın Rus tarihçileri, Eurasia sözü ile yalnız Kuzey Avrasya’yı amaçlamışlardır. Oysa Eurasia Avrupa'nın doğu, Asya’nın orta ve kuzey kesimlerini kapsayan, kapalı tarihî ve coğrafî birlik gösteren, kendine özgü yaşayış biçimi ile önem kazanan ve iki kıta arasında üçüncü bir kıta oluşturan çok geniş bir ülkedir. Bu ülkenin güneyi Kven-Lün, Pamir, Hindukuş ve Kafkas dağları ile sınırlanır. Ayrıca Bkz. L. Rasonyi, Tarihte Türklük, Ankara 1996, s. 1.

20 Tiyen-Şan dağları (Celestial Dağları) Himalaya silsilesine benzer, fakat paralel dizilerden oluşur. Bkz. L.W. Lyde, A Geography of Asia, London 1907, s. 15-16.

21 Altay'ın Al Tayga adından geldiği hakkında Türklük bilgisi âlimlerinden W. Radloff'un görüşü en isabetli görüş olup Prof. Faruk Sümer de Orhun Abideleri'ndeki Altun yış ile bu dağın ifade edildiğinden hiç şüphe duymamaktadır. Çin kaynaklarında geçen Kin-Şan (=Altın Dağ) da bunun tercümesinden başka bir şey değildir (F. Sümer, “Altay Dağları", Türk Dünyası Tarih Dergisi, I/1, (15 Ocak 1987), İstanbul 1987, s. 32). Altay kelimesi Türkçede yüksek orman manasına gelmekte olup uzun bir dăg silsilesinden oluşmaktadır. Bu silsile içerisinde geniş boğazlar ve geçit vermeyen zirveler yer almaktadır. Buna, aşağ1 yukarı paralel olan ve güneyde yüz elliden fazla yerde ortaya çıkan bir diğer zincir ise Türkçe'de Tengri Dağı (Tanrı Dağı) olarak adlandırılır. Çince karşılığı tam olarak Tien Şan’dır. Bkz., L. Cahun, Asya Tarihine Giriş (Kökenlerden 1405'e, Türkler ve Moğollar), (nşr. S. İnan KAYA), İstanbul 2006, s. 12.

22 Kumlu kapı adıyla da bilinen bu geçidin kolay geçilen bir yer sanılmaması gerekir. Geçmişin derinliklerine gidildiği oranda onun, milletler ve kültürler arasında ayırıcı bir çizgi olduğu anlaşılır. Bkz. Rasonyi, s. 1; Tenney, s. 1.

23 Ligeti, s. 15; Kadırgan dağları, güney ucuyla Gobi’nin güney sınırını oluşturan Kuen Lun sıradağlarına bağlanır. Bu dev sıra dağ büyük ölçüde palezoiktir. Bazı coğrafyacılar onun Asya’nın en eskisi olduğunu düşünmektedirler. Kadırgan’ın batısındaki Yeşil Mançurya, Japon Denizi ve Pasifik Okyanusu üzerinden gelen bulutların ıslattı̆̆ı yamaçtır. Bkz., Cahun, s. 16. 
Gobi Çölü'nden geçer ${ }^{24}$ ve coğrafi bir hat boyunca Tibet Platosu'na uzanır. ${ }^{25}$ Türkistan'ın aynı zamanda güney sınırının da başlangıcı olan bu bölgeden batıya doğru Himalaya silsilesini takip ederek dünyanın damı Pamir'e ulaşır ${ }^{26}$ ve bu arada Afgan Türkistan'ı denilen Afganistan'ın kuzey kısmını içine alır. Batıya ulaştığında ise, Hazar Denizi'nin doğu kıyılarını, Ural Nehri'ni, sonra Ural Dağları'nı takiple Türkistan sınırının kuzey çıkış noktasına ulaşır. ${ }^{27}$

Kadırgan Dağları'ndan Karpatlara kadar uzanan bozkırların kuzey ve güney kısımları daha çok koyu kestane rengindeki toprak şeridi ile kaplıdır. ${ }^{28}$ Bozkırların güney sınırında bulunan Hazar Denizi ile Aral ve Balkaş Gölleri'nin kuzey kesimleri boyunca uzanan verimli otlaklar Altay Dağları'nda kesilir, ancak, Altayların doğu eteklerinde yeniden ortaya çıkarak Kadırgan Dağları'na kadar 45'inci kuzey enleminin üstünde devam ederler. ${ }^{29} \mathrm{Bu}$ şeridin güneyinde uzanan kumlu bozkır, yer yer çöllerle son bulur. Bu kumlu bozkır bölgesi Altay Dağları'ndan batıya ve doğuya doğru yayılan daha verimli bozkır şeritlerini birbirine bağlar. ${ }^{30}$

Türkistan'ın nehirleri, nehirlerin akış yönlerini tayin etmesi bakımından kıtanın dağ sistemleriyle son derece yakından ilişkili olup bu nehirlerin varlığı Türkistan tarihi bakımından

24 Altay ve Tanrı dağlarının hemen doğusunda bulunan geniş ve uçsuz saha tüm kıtanın yalnızca beşte birini kaplar. İklim ve görünüş bakımından bir tekdüzeliğe sahip bu bölge büyük Gobi Çölü tarafından adeta iki tabii bölgeye ayrılır. Bu bölgenin kuzeyi kısmen daha az yüksek ve daha dardır. Kuzey bölgesinin en karakteristik özelliği çok şümullü ve oldukça çorak toprakların hâkim olması ve doğudan batıya doğru uzanan hafif kabarık dağcıkların yer almasıdır. Güney bölgesinin en belirleyici özelliği ise, dünyanın en yüksek platolarından birisi olan Tibet platosunun burada yer alması ve yine dünyanın en yüksek dağ silsilelerinden birisini oluşturan Himalayaların bu bölgeye açılmasıdır. Bkz. Lyde, s. 11.

$25 \quad 1.000$ km'ye 2.500 km'lik bir yer kaplayan bu platonun ortalama yükseltisi $4.500 \mathrm{~m}$ civarındadır. Genellikle Büyük ve Küçük Tibet olmak üzere iki kısma ayrılan Tibet Platosu, tepe ve dağlar üzerinde plato ve nehir havzaları üzerinde göllerin yer aldığg Büyük Tibet'e nazaran, Küçük Tibet, Kven-Lün yönünde Himalaya ile daha çok temas etmekte olup daha çok kıvrımlı toprakları ihtiva etmektedir. Bkz. J.T. Walker, “Tibet”, Asia, (nşr. A.J. Herbertson), London 1903, s. 105-106.

26 Bâm-i Dünya (the root of the world-Dünya Çatısı) adıyla da bilinen Pamir [Cahun, s. 12], büyük Asya kıtasının en yüksek dağ silsilelerinden biri ve Asya'ya çekirdek olma bakımından en uygun olanıdır. Ceyhun (Amuderya) ve Seyhun (Sir Derya)'un da kaynağını teşkil eden bu yaylanın yüksekliği ortalama 7495 metre olup, çok sarp ve geçişi imkânsız vadileri ihtiva eder. Bkz. Lyde, s. 14.

27 Ligeti, s. 15.

28 Toprak Asya'nın her iki havzasını tek tip bir tabakayla örtmemektedir. Türklerin Kum olarak adlandırdıkları değişik ölçeklerdeki karışımla ve önceden Hazar Denizi’nden Baykal Gölü ve Sarı Nehre kadar uzanan denizin tuz depolarıyla karışarak üç farklı hamur oluşturmuştur; biri düz su geçirmez, diğeri silisli kilden, üçüncüsüyse sert ve tuzlu fakat her üçü de insana asidir. Bkz. Cahun, s. 16.

29 Passarge tarafından Salzsteppe (Tuzlu Bozkır) adı verilen güney bölge, kuzey bölgesinden daha küçüktür. Yağışı az ve kapalı havza olması nedeniyle toprağı da tuzludur. Bununla birlikte, bazı alanları verimli topraklarla kaplı olup, sulama yolu ile daha iyi duruma getirilebilir. Irmaklar boyunca hayvan yetiştirmeye elverişli otlaklar da vardır. Bu bölgenin tipik hayvanı devedir. Bu husustaki bilgiler için bkz. Rasonyi, s. 1-2.

30 Türkistan’ın büyük bir kısmını oluşturan çöl denizleri çok geniş bir sahayı kapsamakta ve bu noktada, Orta Asya coğrafyasında yukarıda da değindiğimiz gibi yüksek dağ dizilerinden olan Tiyenşan-Pamir silsileleri bahsi geçen bu çöl denizleri içinde adeta bir yarımada görünümündedir. Batı Türkistan'ın coğrafî̀ sınırlarına nazaran Tiyenşan-Pamir dağ dizisinin batı bölümleri ancak onda bir kadar çok küçük bir bölümü oluşturur. Dolayısıyla kalan dokuzu hep çöller ve bozkırlardan ibarettir. Diğer taraftan, Batı Türkistan'ın bozkırları, Tiyenşan dağlarının Seyhun güneyinden batıya uzanan "Kara Tav" Karaçuk Dağları'yla Aral Gölü ve Hazar Denizi arasındaki Üst Yurt irtifaının güney sınırları istikametinde uzanan bir çizgi ile Güney ve Kuzey Bozkırları diye ikiye ayrılabilir. Bkz. Togan, Bugünkü Türkili (Türkistan) ve Yakın Tarihi I, s.14. 
hayatî önem arz etmektedir. ${ }^{31}$ Bu nehirlerin en önemlilerinden olan ve kaynağını Pamir'den alarak Aral Gölü'ne dökülen Amuderya (Ceyhun) ${ }^{32}$ ve Sirderya (Seyhun) 1rmakları coğrafya için adeta can damarı sayılabilecek konumdadır. ${ }^{33}$ Bölgede bu iki nehir dışında, Balkaş Gölü’nün hemen kuzey doğusunda yer alan Altay Dağları'ndan kaynağını alan İrtiş ve Obi, Sayan Dağları'ndan kaynağını alan Yenisey ve Lena Irmakları Türkistan'ın diğer önemli nehirlerinden olup yılın belirli zamanlarında akmaktadırlar. ${ }^{34}$ Öte yandan Kansu Vadisi'nden başlayıp Çin içlerine kadar uzanan Wei Irmağı ise Doğu Asya’yı Türkistan'a bağlayan önemli bir geçit durumundadır. ${ }^{35}$

İnsanoğlunun beşiği olarak tanımlanan Türkistan, ${ }^{36}$ en eski çağlardan itibaren pek çok medeniyete ev sahipliği yapmış ve bu vesileyle özellikle de çeşitli kültür merkezlerinin ortaya çıkarılmasından sonra ${ }^{37}$ yerli ve yabancı âlimler tarafından birden fazla kavme (Hint-Cermen kavimleri gibi) ${ }^{38}$ ana yurt olarak işaret edilmiştir. Öte yandan, her ne kadar Türkmenistan' da Aşkabat yakınındaki Anau Harabeleri'nde yapılan arkeolojik izlenmeler M.Ö. 4500, diğer bir tahmine göre

31 Kıtanın su çizgisi sınırını da oluşturan bu nehirler, özellikle anahtar durumundadırlar. Bu nehirlerin pek çoğu Kuzeybatı, güney ve doğu-batı istikametinde akarlar. Asya nehirleri okyanuslara ve kıta içerisinde yer alan göllere ya da bataklıklara dökülmeleri bakımından iki ana grupta incelenebilirler. Kıta içine dökülen nehirlerin büyük kısmı Aral Gölü ve Tarım havzası etrafındaki bölgelerde yer almaktadır. Bu noktada Aral gölünün Ceyhun ve Seyhun nehirleri tarafından beslendiği de unutulmamalıdır. Bkz. Lyde, s. 16-17.

32 Latince Oxus adıyla da bilinen Amuderya'nın uzunluğu 2494-2540 km'dir. Şu anda kullanılan İran kökenli Amu ismi adını Amul kasabasından almış olup zaman zaman nehrin yer değiştirdiği rivayet edilir. Sasani zamanlarında ise nehir Weh-Road, olarak adlandırılıyordu. Müslüman Araplar ise genellikle Diayhûn ismini kullanıyorlardı. Bu nehir Çinlilerde ise Kui-shui, Wu-hu ya da Po-tsu olarak temayüz etmektedir [B. Spuler, "Amû-Daryâ," Eİ/I, Leiden 1986, s. 454-457]. Bu nehrin kuzeyine ise Müslüman Araplar Maveraünnehir (Nehir Ötesi) adını veriyorlardı [G.Le. Strange, The Lands of the Eastern Caliphate (Mesopotamia, Persia, and Central Asia from the Moslem Conquest to the time of Timur), New York 1873, s. 433]; diğer taraftan bahsi geçen nehrin İran ile Turan arasında sınır kabul edilmesi Taberî̀nin kayıtlarına göre bir efsaneye dayandırılmaktadır. Buna göre, aralarında ihtilaf bulunan Efrasyap ile Minuşehr barışarak, aralarında, Minuşehr'in Erşisiyatir adlı bir adamı tarafından fırlatılacak bir ok atımı genişliğindeki araziyi sınır olarak tespit etmişler ve İrş (Erşisiyatir’in kısaltması) tarafından atılan ok Türk memleketinin neresine düşerse, orası sınır olacak, iki taraftan hiç birisi bu sınırı geçmeyecekti. Tanrının verdiği kuvvetle onun Taberistan'dan attığı ok Belh (Amuderya) ırmağına düştü ve böylece Belh ırmağı İran ile Türk yurdu (Turan) arasında tarihi bir sınır teşkil etti. Bkz. Taberî, Milletler ve Hükümdarlar Tarihi II, (nşr. Z. Kadirî Ugan-A. Temir), İstanbul 1992, s. 534.

33 Güney bozkırlarının ırmakları Aral gölü istikametinde akan Sir Derya (uzunluğu $1886 \mathrm{~km}$ ) ve Amu Derya (uzunluğu 2350) ile kollarından Oghış, Kâfirnihan, Surkhan, Aksaray, Çırçık ve yahut vaktiyle onların kollarını teşkil eden ırmaklardan Belkhâb, Zeref̧̧an, Kaşka Derya, Sokh gibi ırmaklardan ibarettir. Zamanımızda bunlardan Sir Derya'dan 1.706.403, Amu Derya'dan $300.000 \mathrm{~km}$ kare ve Zerefşan'dan 400.000, Çırçık'dan 154.000 hektar toprak sulanmaktadır. Irmakların aktığı Aral Gölü ise güney bozkırlarının tek büyük gölüdür. Bkz. Togan, Bugünkü Türkili (Türkistan) ve Yakın Tarihi I, s. 1617.

34 Bkz. E. Reclus, The Earth and Its Inhabitants ASİA I, (nşr. A.H. Keane), New York 1891, s. 12.

35 Little, s. 22.

36 F.H. Skrine-Ross, E. Denison., s. 3.

37 Genel olarak müracaat edilebilir. İ. Kafesoğlu, Türk Milli Kültürü, İstanbul 2005; İ. Kafesoğlu, Türkİslam Sentezi, İstanbul 2008, s. 1 vd; Cahun, s. 16vd.

38 Hint-Avrupa kavimleri veyahut Almanların kullandıkları tabir olan Hint-Cermen kavimleri tabiri hakkında Köprülü, bahsi geçen bu kavimlerin antropolojik manasıyla bir ırkî birlik teşkil etmediklerini ve bu tabirin yalnızca bir dil ailesini ifade eden linguistik bir mefhum olduğunu ifade etmiştir. Bkz. M. Fuat Köprülü- Barthold, W., İslâm Medeniyeti Tarihi, Ankara 2004, s. 97. 
9000 yıllarında yaşamış olan bir medeniyeti meydana çıkarmış olsa da burada ele geçen eşyalara tesmiye olunan kavimlerin milliyetini tayin etmek için elde şimdilik yeterli delil yoktur. ${ }^{39}$ Ancak son asırda yapılan bir kısım arkeolojik kazılarda ele geçen veriler tarihi açıdan bölgenin en eski sakinleri ya da daha doğrucası ilk proto insan tipi hakkında dikkate değer bilgiler sağlamıştır. ${ }^{40}$ Belli bir sistem arz eden ilk buluntular, Altay Dağları'nın kuzeyinde, Yenisey Irmağı'nın yukarı boylarındaki bozkırlarda gelişmiş M.Ö. 2500-1700 arasına tarihlenen bir kültüre işaret ediyor ki, bulunduğu yere nispeten bu kültüre Afanas'evo Kültürü denir. ${ }^{41}$

M.Ö. üçüncü binin sonlarına doğru aynı menşeli bir dile bağlı, az ya da çok farklı lehçelerle konuşan bir halk topluluğu olarak temayüz ettiğini gördüğümüz Arilerin istilasını ${ }^{42}$ ve M.Ö. ikinci yüzyılın ortalarında Greko-Bactria Krallı̆̆ı'nın önce kuzey sonra güney bölgelerini ve hatta Hindistan'ın bazı şehirlerini ele geçiren, ${ }^{43}$ Yunan kaynaklarında İskit ortak adıyla zikredilen Sakaları ve bu konudaki tartışmaları bir kenara bırakacak olursak, ${ }^{44}$ bugünkü Moğolistan'ın yerlileri olan, Türklerle aynı dili konuşan ve aynı menşeden gelen Hunlar (Hyung-Nu), ${ }^{45}$ milattan iki yüz

39 Burası o devirde Önasya (Sümer ve Şus) ve Güney Asya'da (Hindistan'da Sind nehri havzasında Mehen-Jo-Dero ve Harappa harabelerinde) ve Uzak Doğu'da (Çin'de Yunan vilayetinde, Yang-shao'da ve Mançuride) eserleri keşfolunan medeniyetler arasında bir vasıta yahut onların ilk başlangıç merkezi, ocağı olmuştur. Anau'da bulunan eserler insanın ilk medeni tekâmül safhalarını öğrenmek bakımından çok mühimdir; fakat burada yakılmış ceset enkazını muhtevi bir alt tabakanın üstünde bulunan yuvarlak (brakisefal) kafalar, keza Türkmen elişlerinde görülen ziynetlerle müşterek hatlara malik keramikler bulunmuş ise de bu hususlar, o eski zamanlarda bu bölgede yaşamış olan ahalinin milliyetini tayin etmek ve bunları Türklerin malı olarak kabul eylemek için kâfi gelmez. Bkz. Togan, Umumî Türk Tarihi’ne Giriş, s. 7-8.

40 Türklerin tarihini anlatmadan Ortaçağ Asya tarihini anlamanın imkânsızlığından bahseden L. Cahun, bir kısım linguistik verileri de göstererek, batıda Fince ve Macarca, doğuda ise Moğol ve Mançu dilleri arasındaki benzerlikleri ifade ederek bunlar arasında ortak bir kökenin sezilebileceğini ve aynı aileden olduklarını ileri sürmüştür. Dolayısıyla Türkistan halklarının kökenine bakılırken her ne kadar bahsi geçen bu kavimler arasında kesin bir akrabalık ve soy birliği bulunmasa da birbirleriyle karşılaştırıldıklarında çok açık bir şekilde tanımlanabilecek ve karakterize edilebilecek bir dil ailesi ortaya çıkar. Bu dil ailesi dörde ayrılır: Fin-Ugor, Türk, Moğol ve Mançu dil aileleridir. Bkz. Cahun, s. 28-29.

41 Bunu yaklaşık aynı bölgede, M.Ö. II. bin başlarından itibaren sarı ırkın hâkim göründüğü Okunevo Kültürü izler. Bunu da tekrar beyaz insanların hâkim olduğu Andronova Kültürü izler. Bu kültürün Karadeniz bozkırlarından Yenisey boylarına kadar pek çok akrabası vardır. Diğer taraftan Minusa bozkırı olarak da bilinen Yenisey-Altay arasındaki bölgede M.Ö. 1300-800 yıllarına tarihlenen Karasuk Kültürü göze çarpar. Bunu ise, M.Ö. VIII ile I. yy’lar arasında yer alan Tagar Kültürü takip eder. Bu tabaka nispeten iyi çalışılmıştır ve ele geçen öğeleri Türk kültür unsurları ile telif etmek çok kolaydır. Bkz. O. Karatay, İran ile Turan (Hayali Milletler Çağında Avrasya ve Ortadoğu), Ankara 2003, s. 29-30.

42 Aryanlar hakkında ayrıca bkz., P. Giles, "The Aryans", The Cambridge History of India I, Ancient India, (nşr. E.İ. Rapson), Delhi 1955, s. 65; Aryanî ve Ural-Altay kavimlerinin karşılıklı itişmeleri hakkında bkz. Togan, Bugünkü Türkili (Türkistan) ve Yakın Tarihi I, s. 44-47.

43 Sakaların Hindistan'a inmeleri ve buralardaki faaliyetleri hakkında bkz. E.J. Rapson, "Scythian and Partian Invaders", The Cambridge History of India I, (nşr. E.J. Rapson), Dehli 1955, s. 508-529; V.A. Smith, "The Kushan, or Indo-Scythian, Period of Indian History (B.C. 165 to A.D. 320)", JRAS, (1903), London 1903, s. 1-64.

44 V.V. Barthold, Orta Asya Tarih ve Uygarlık, (nşr. A. Batur), İstanbul 2010, s. 21; İskit adı, İskitler, İskitler'in yayıldıkları coğrafya, Çin'in kuzeybatısından Hazar'a, Hazar'dan Tuna'ya kadar ve Ön Asya'da İskitler, İskitlerin kökenleri meselesi, İskitlerin dili ve yazısı, dini, gelenek ve görenekleri ve sanatları hakkında yapılmış mühim bir çalışma hakkında bkz. İ. Durmuş, İskitler (Sakalar), Ankara 2008, s. 1 vd.

VII. Yüzyıla gelindiğinde Çinliler kuzey ve güney yollarını kullanan ve sınırlara ulaşmış bulunan Türkleri uzun zamandan beri tanımaktaydılar. Bu topluluklara taktıkları eski ad Hyung-Nu'ydu. Bu 
sene öncesinden beri Türkistan'da dağınık vaziyette bulunan göçebeleri kudretli bir konfederasyon halinde birleştirmişlerdi. ${ }^{46}$ Dolayısıyla daha sonraki yüzyıllarda İslamiyet' in intişarından evvel bölgede hâkim Türk devletleri Hunlar, ${ }^{47}$ kültürleri üzerinde Hun menşeleri tespit edilen Avarlar ${ }^{48}$ ve Hunlardan geldikleri konusunda bütün Çin kaynaklarının ittifakla bildirdikleri Gök-Türk (KökTürk)' ler olmuştur. ${ }^{49}$

O tarihlerden itibaren Türkistan coğrafyası ağırlıklı olarak Türk ve Moğol ulusları tarafından yerleşilerek yurt olarak kabul edildi. Toprakların daha az verimli oluşu ve geniş bozkırların daha çok yer kaplaması nüfusun dağılımında başlıca etken olmuştu. ${ }^{50}$ Öte yandan yaşanılması çok zor ve iklim bakımından insan hayatının devamı için oldukça olumsuz özellikleri barındıran bu coğrafya, ${ }^{51}$ Türklerin ekonomik alanda hayvan yetiştirmeyi geliştirme ve sosyal alanda da olağanüstü devlet

hiçbir milliyet ya da etnik karakter belirtmeyen Türkçe ya da Moğolca bir anlamı olmayan Çince ve çok eski bir sözcüktür. Dolayısıyla Çinliler, Hoang-Ho nehrinin kuzeyinde yaşayan ve hemen hemen hepsi göçebe olan bu halkları Hyung-Nu ortak adıyla adlandırmışlardı, tıpkı Yunanlıların Tuna'nın kuzeyindeki bölgenin batısında yaşayanlara Selt, doğusunda yaşayanlara $\dot{I}_{s k i t}$ adını verdikleri gibi. Bkz. Cahun, s. 35; ayrica bkz. O. Maenchen-Helfen, "Archaistic Names of the Hiung-nu", The Central Asiatic Journal, 6/I, Wiesbaden 1961, s. 249-260.

46 Grenard, s. 13-15.

47 Dünyanın en eski yazılı belgeleri olarak kabul edilen Çin Tarihi Yazıtları veya orijinal adıyla Şi Ki’nin 110. Bölümünde Huong-no (Hunlar) hakkında, onların ilk atalarının Hiya Hanedanlığı soyundan olup adı Sun-ui (Sun-oi) olduğu kaydedilmiştir. Buna göre Hia veya Hiya hanedanlığının etnik kimliği tam olarak kanıtlanamasa da M.Ö. 23-19. yüzyıllar arasında bugünkü Moğolistan ve Çin'in kuzey bölgelerinde hüküm sürdüğü düşünülmektedir. Ancak, Kuzey Çu döneminde (M.S. 556-581) başkent Çungan'da Kök Türk Kağanı onuruna inşa edilen T'u-küe/Türk Tapınağı'nın duvarına işlenen Türk Kağanı Muhan, Hiyahou/Hun soyundandır. $O$, Gök Tanrt tarafindan tayin edildi ifadeleri Kök Türklerin bu hanedanlık ile olan menşe birliğini göstermesi bakımından dikkate şayandır. Bkz. J.M. De Groot-G.A. Asena, 2500 Ylllık Çin Imparatorluk Belgelerinde Hunlar ve Türkistan, İstanbul 2011, s. 34.

48 Bu Türk kavmi Türkistan'da Juan-Juan adıyla tanınmakta ve Batı Türk Devleti (Gök Türk)'ne mensup durumdaydılar. Bu devlet içerisinde baş gösteren mücadeleler neticesinde Avarlar, VI. Yüzyılın ortalarına doğru (552'de) Karadeniz'in şimaline gelmişler ve Karpatlara kadar ilerleyerek Slav topluluklarıyla münasebete girmişlerdi [A.N. Kurat, "Doğu Avrupa Türk Kavim ve Devletleri”, Türk Dünyası El Kitabl I, (Coğrafya-Tarih), I-A-23, Ankara 1992, s. 178]. Avarlar ve Avar kültürünün Hun menşeleri hakkında bkz. B. Ögel, İslamiyet'ten Önce Türk Kültür Tarihi (Orta Asya Kaynak ve Buluntularına Göre), Ankara 1988, s. 114.

49 Gök-Türklerin Hunlardan geldikleri hususundaki kayıtlar için bkz. A. Taşağıl, Gök-Türkler I, Ankara 1995, s. 9-10; ayrıca bkz. A. Von Gabain, "Köktürklerin Tarihine Bir Bakış”, D.T.C.F.D., C.II, S.V, Ankara 1943, s. 685-695.

50 Türkistan'da yer alan kurak ve soğuk çöller ve az yağış alan bölgeler tabii olarak daha az nüfusu barındırır. Toprakların fazla verimli olmayışı da bu ayrıca etken olmuştur. Bu coğrafyada en verimli topraklar Yukarı Yenisey ve Maveraünnehir bölgesinde bulunur. Bkz. J.B. Reynolds, Regional Geography Asia, London 1908, s. 30.

51 Türk milletinin bozkırlarda yaşayan büyük bir bölümünün seciyesine ve mukadderatına bozkırların tesiri büyük olmuştur. Batılı müellifler tarafından (mesela Leon Cahun) bozkırın ürünü olarak tanımlanan Türkler, bu coğrafya sayesinde öğrendikleri binicilik ve askerlik maharetleriyle her tarafa koşmuşlar, Çungarya'da ata bine Türk hiç inmeden doğuda Çin'in Sarı ırmağı ile batıda Doğu Avrupa'nın Tuna ırmağına kadar akınlar düzenleyebilmiştir. Öte yandan bozkırdaki çetin hayat Türkleri gövdece küçük, fakat çok sağlam ve dayanıklı, herhangi bir güçlüğe, açlığa, susuzluğa, sıcağa ve soğuğa dayanır bir hale getirmiş, sahra kadar geniş kalpli, kıskançlıktan uzak yapmıştı. Aynı zamanda bozkır, Türklerin bindikleri küçük ve sağlam atlarını da kendilerine benzetmişti. Bkz. Togan, Bugünkü Türkili (Türkistan) ve Yakın Tarihi I, s. 19-20. 
kurma yeteneğinin ortaya çıkmasını tetiklemiştir. ${ }^{52}$

Türkistan'ın jeopolitiğine baktı̆̆ımızda bu coğrafyanın önem kazanmasında, son yüzyılda gerçekleştirilen iki önemli arkeolojik keşif ile; birincisi Almanya Halstatt'ta zengin bir Seltik mezarında ele geçen ve M.Ö. VI. yüzyıla tarihlenen bir Çin ipeğinin keşfedilmesi, ikincisi ise Altay Dağları'nda gerçekleştirilen kazılarda ele ele geçen M.Ö. V-III. yüzyıllara tarihlenen bir Çin ipeği ve bir kısım bronz aynaların bulunması ve bütün bunların eski zamanlarda Çin ile Batı arasında bir iletişim veya bu iletişimin yapıldığı tarihi bir yolun var olup olmadığ tartışmalarına girmezsek, ${ }^{53}$ daha kesin bilebildiğimiz ve M.Ö. II. yüzyılda Çin'den Ön Asya'ya açılan ana kervan yolunun (tarihî İpek Yolu) önem kazanmasıyla belirginleşen bir durum söz konusudur. Bu yol vasıtasıyla Çin ipeği dışarı ihraç edilmiş, ${ }^{54}$ aynı yolla batıdan, Greko-Roma dünyasından Çin'e cam ve kristal getirilmişti. Doğunun etkisiyle madenciliğin ortaya çıkması gibi, batının etkisiyle de Orta Asya cam imalatı başlamıştı. ${ }^{55}$

52 Devlet kurma yeteneğinin neden yalnız Ural-Altaylı kavimlere ilişkin olduğu sorulursa bunun cevabı basittir. Ural-Altaylı kavimlerin yukarıda bahsettiğimiz iki başarısı arasında bir bağlantı olması gerekir. Büyük sürülerin yönetimi ve bakımı, geniş alanlarda sürekli dolaşma, otlak ve mülk hukuku bakımından kaçınılması imkânsız çatışmalar, oymak örgütleri, hayvan yetiştirici göçebelikle ilgili her şey birbiri ile sıkı sıkıya bağlıdır. Bunun doğal sonucu olarak görüş ufku genişler, cesaret, oymağa bağlılık bilinci, hükmetme gururu, örgütçülük yeteneği, özetle, devlet kurmak için bütün nitelikler genişler. Bu ruhsal yetenek ve beceri ile yetişen insanlar, çiftçi kavimleri yendikten sonra, sürülerini barındırma olanaklarına da sahip doğuştan egemen öğe ve devlet kurucusu oluverirler. Bkz. Rasonyi, s. 18-19.

53 Tarihi ipek yolunu açılması ve önem kazanmasında, yakın zamanlara kadar, bir Çinli olan Zhang Qian'ın batı bölgelerine yaptı̆̆ 1 seyahatin çok önemli bir rol oynadığı düşünülmekteydi. Ancak bu yolun önem kazanmasında Büyük İskender'in doğu yönünde giriş̧tiği seferlerin de etkisinin olduğu yadsınamayacak bir gerçektir. Zira O'nun imparatorluğunu yaratması ve böylece Helenistik dünyanın doğuya doğru genişlemesi ve dikkate şayan başarıları, Grekler ve Doğu dünyası arasında temas ve iletişimi artırdı. Böylece de ipek yolunun ortaya çıkması için tabii bir ortam hazırlanmıştı. Tabi bu arada İskender öncesinde eski dünya medeniyetleri arasında belirli ilişkilerin yaşandığı unutulmamalıdır. Greklerin bile ipek üretimini doğudaki bir ülkeden öğrendikleri rivayet edilir. Tarihçi Ctesias (M.Ö. V-IV. yy) bu ülkeyi Seres olarak adlandıran ilk Grek olarak iddia edilir. Yine Grek tarihçi Herodot, doğuya Issedones topraklarına seyahat eden Aristeas adlı bir seyyahtan bahseder. Bazı Çinli bilim adamlarının tahminlerine göre Issedones toprakları kabaca Ural dağlarının doğu mıntıkalarından Tanrı ve Altay dağlarına hatta Tarım havzasına kadar uzanan sahayı kapsıyordu. Bkz., Y. Juping, "Alexander the Great and the Emergence of the Silk Road", The Silk Road, V.6., No.3 (Winter-Spring 2009), (nşr. D.C. Waugh), Washington 2009, s. 15.

54 Burada çok ince bir ayrıntıya dikkat çekmekte fayda var. Orta zamanlarda ticaret çok iyi ve bol kazançlıydı. Ama tabii ekonomi şartlarıyla yaşayan halk kitlelerine değil, sosyal seviyesi yüksek, lüks tüketime ihtiyacı olan kesime hizmet veriyordu. Mesela Çinliler imparatoriçeleri için İran'dan son derece pahalı ve ender bulunur sürme getirirlerdi. Babil halıları da keza ender mallar arasındaydı. Ve nihayet Çin'e Suriye'den gerçek ve ince işçilik örnekleriyle süslü değerli taşlar, Kızıl Deniz'den inci ve mercanlar, Suriye ve Misır'dan kumaşlar, Küçük Asya'dan uyuşturucular getirilirdi. Ama Auquste zamanından itibaren Avrupa'da kullanılmaya başlayan ipek, bu eşyalar arasında en önemli yer tutuyordu. İpeğe duyulan ihtiyaç öylesine fazlaydı ki, aristokratlar ve saray mensupları arasında döviz birimi olarak kullanılıyordu ve hatta savaşa katılan askerlere ücret olarak ipek veriliyordu. Bkz. L.N. Gumilev, Eski Türkler, (nşr. A. Batur), İstanbul 2011, s. 62.

55 Çin ile başlayan ticaretten aslan payını önceleri Part hanedanı Arşakiler, daha sonra Pers hanedanı Sasaniler zamanında İran alıyordu ve Çin'le Roma İmparatorluğu arasında doğrudan ticari ilişkilerin kurulmasını engellemek için her türlü yola başvuruyordu. Sasaniler zamanında en önemli uluslararası kara ve deniz ticaret yolları Perslerin eline geçmiş; Greko-Bactria kültürünün kalıntıları ve Çin ve Hint etkisiyle Orta Asyalı İranlıların, özellikle de Soğdiyanların uygarlık seviyesi yükselmişti. Bkz. Barthold, Orta Asya Tarih ve Uygarlik, s. 23. 
Bu arada, Türkistan’ı kuzey ve güney olmak üzere iki tabii bölgeye ayıran Tanrı dağları, hem halkların yerleşme ve medeniyet çeşitlerine ayrılmaları yönünden bir sınır vazifesi görmüş, hem de doğu-batı yönünde uzanan yolların ikiye ayrılmasına sebep olmuştur. Dolayısıyla farklı özellikleri ve işleyişleri olan bu iki yol tipinden birincisi yani güney Türkistan yolları doğuda Çin'den başlayıp Suriye ve Anadolu limanlarında son bulduğu halde, ikincisi yani kuzey Türkistan yolları bir merkezden, Orkun bölgesinden çıkmıştır. ${ }^{56} \mathrm{Bu}$ iki yol güzergâhları arasındaki temel fark, güneydeki yolların hemen münhasıran ticari yollar olmasına karşılık, kuzeydeki yollar, Kırgızlardan güneye doğru uzanan çelik yolu diyebileceğimiz yol gibi birkaç yol müstesna hemen tamamiyla askeri yollardır. ${ }^{57}$

Öte yandan yukarıda kısmen değindiğimiz, VI. yüzyılda kurulan ve sınırları İran ve Bizans hudutlarına kadar ulaşan Gök-Türkler (Kök-Türk) ${ }^{58}$ bir taraftan Ak-Hunları ortadan kaldırmış, bir taraftan da İran ve Soğdiyanlar ile İpek Yolu ticareti için mücadeleye girmişlerdi. ${ }^{59} \mathrm{Bu}$ arada ipek ticaretini tekellerine alan Soğdiyanların ${ }^{60}$ ticari çıkarları hem Türklerin İranlılarla ilişkilerinin kopmasının ve hem de Türk devleti ile Bizans arasında diplomatik ilişkilerin kurulmasının da

56 Kuzey Türkistan yollarının Orkun bölgesinde toplanmasının sebebi, bu bölgenin stratejik öneminden ileri gelmektedir. Bu önem dolayısıyladır ki, Türkistan'da hâkimiyet kuran bütün kavimlerin yaptıkları iş, bu bölgeye vakit geçirmeden yerleşmek olmuştur. Gerçekten, Hunlardan Çingizlilere kadar Orkun bölgesi istisnasız hep başkent vazifesi görmüştür. Bununla birlikte bu kavimlerin Orkun bölgesinin hep aynı yerlerinde oturmadıklarını görüyoruz. Bunlardan Türkler, Uygurlar ve Moğollar aynı bölgenin ayrı ayrı yerlerinde oturmuşlardır. Türklerin Ötüken dağlarını seçmelerine karşılık, Uygurlar KaraBalgasun (Ordu-Balık) ve Çingiz Moğolları da Karakurum denilen yerde oturmuşlardır. Bu itibarla Orkun bölgesinin ve bilhassa bu bölge içindeki Ötüken dağlarının yerinin tespitinde zaruret vardır. Bkz. C. Gökalp, Kaynaklara Göre Orta Asya’nın Önemli Ticari ve Askeri Yolları (M.S. 552-999), Ankara 1973, s. 5-6.

57 Gökalp, s. 6.

58 Kök Türk adı, Kök-Türk kağanlığının kuruluşu, yükselişi ve zayıflaması, yeniden yükseliş ve altın çağları, Kök-Türk hakanlığında hâkimiyet anlayışı ve idari mekanizma hakkında daha fazla bilgi için bkz. Sadettin Gömeç, Kök Türk Tarihi, Ankara 2003, s. 1 vd.

59 Ak-hunların ortadan kalkmasıyla Gök-Türk devleti, batıda tam anlamıyla Sasani imparatorluğuyla sınır olurken, aynı zamanda siyasi olarak çağının dünyasının iki büyük devleti Bizans ve Sasanilerle temasa geçmiş, onlarla bir seviyeye yükselmişti. Bundan sonra Sasani hükümdarı Anuşirvan, Batı GökTürklerine vergi vermeye başlamıştı. Bununla birlikte yeni siyasi gelişmeler olamaya başladı. Sasani İmparatorluğu Maveraünnehir ticaret yolunu tamamen eline geçirmek istiyordu. Bu sebepten ülkesinden Akdeniz ve Bizans limanlarına yapılan ipek ticaretini durdurdu. Bu şekilde Gök-Türklere bağlanmış olan tüccar Soğd kavmini ekonomik zorluklara sokacak, hem de Gök-Türkleri ipek transit vergisinden mahrum edecekti. Ayrıca İstemi’nin gönderdiği elçileri hile ile öldürttü. Bu bağlamda daha önce gönderilmiş iki elçilik heyetine de iyi davranmayan Anuşirvan, birinci heyetin getirdiği ipekleri hemen satın alıp elçilerin gözü önünde yakmış, elçiler geri dönmüş, ikinci elçilik heyetini de gizlice zehirleterek öldürmüş, İran sıcağına dayanamadıkları için kendileri öldükleri yalanını yaymıştı. Bkz. Taşağıl, s. 32.

60 Soğd ülkesi, Amuderya ile Sirderya arasındaki bölge idi. Ticaretle uğraşan Soğdlular Türkistan’a yayılmış ve yer yer koloniler kurmuşlardı. Ayrıca bu bölgedeki ipek yolu ticareti de tamamen onların elinde bulunuyordu. Gök-Türk Devleti’nin bilhassa ilk zamanlarında Soğdlular, Gök-Türk kağanlarına müşavirlik etmişlerdi. Mesela Bizans imparatorluğuna Gök-Türk kağanı tarafından elçi olarak gönderilen Manyah adlı şahıs bir Soğdlu idi. Gök-Türk kağanlarının batı âlemi ile hakkındaki bilgileri de daha ziyade Soğdluların verdikleri haberlere dayanıyordu. Takip eden yıllarda Türkistan'ın her tarafına dal budak salarak koloniler kuran Soğdlular, neticede siyasi ve kültürel rollerini iyice artıracaklar ve Uygur çağında Uygurlar üzerinde çok müessir olacaklardır. Bkz. Ögel, İslamiyet’ten Önce Türk Kültür Tarihi.., s. 188. 
sebebiydi. ${ }^{61}$

Moğol istilasına kadar Türkistan'ın en önemli devletleri olarak temayüz eden Selçuklular, Gazneliler ve Karahanlılar bu coğrafyanın jeopolitik bakımdan öneminin farkındaydılar. ${ }^{62}$ Nitekim daha İslamiyet'in zuhuru esnasında Türkistan Türkleri ile Müslüman Araplar arasında siyasi, iktisadi ve sosyal yönde bir takım münasebetler yaşanacaktır. ${ }^{63}$ Söz konusu bu devletler bir taraftan müslümanlaşarak İslam dünyası ile sık1 ilişkilere girecekler, ${ }^{64}$ bir taraftan da Türkistan'ın kilit noktalarına hükmedebilmek için birbirleriyle amansız bir mücadeleye girişeceklerdi. ${ }^{65}$ Tarihin hemen her devresinde bu mücadelenin merkezinde yer alan Çin ise, dünya ticareti ve hâkimiyeti bakımından kalp-gâh durumunda olan bu önemli kilit noktalarını kendi elinde tutmak istemiş, bu maksadını gerçekleştirebilmek için daha Hunlar zamanından başlayarak bilhassa Türk iktidarlarıyla kıyasıya mücadeleye girişmişti. ${ }^{66}$ Zira bu coğrafya zengin ve daha gelişmiş bölgelere açılan birçok yollarıyla adeta bir geçişs sahasıdır. Dolayısıyla en eski devirlerden itibaren bu hakikatin farkında olan Türk devlet adamları da bu önemli şah damarlarını güçlerinin yettiği kadar ellerinde tutmaya çalışmışlardır. ${ }^{67}$

Diğer taraftan XI-XII. yüzyıllarda tarihi İpek Yolu ticaretinde yeni bir canlanma meydana gelecek, büyük ve tarihsel yolda sürekli ve düzenli kervanlar çalışmaya başlayacaktır. Bu hususta

61 Pers kralı Anuşirvan'ın, Türk devletiyle irtibatını bu menfi hareketiyle koparmasından sonra Gök-Türk Devleti, kendi hâkimiyeti altında bulunan Soğdiyana ülkesini yöneten bir temsilciyi Bizans İmparatorluğu nezdine gönderdi. Misyonunun amacı Romalılarla doğrudan temasa geçerek Pers topraklarından hiç geçmeden yapılacak bir ipek ticaretinde tekel hakkı istemekti. Bkz. Cahun, s. 33; Barthold, Orta Asya Tarih ve Uygarlik, s. 24.

62 Togan, Bugünkü Türkili (Türkistan) ve Yakın Tarihi I, s. 95-101.

63 Kuteybe b. Müslim'in Türkistan'a yönelik politikaları, askeri seferleri, bu dönemde Türkistan'ın önemli şehirleri, şehirlerin sosyal ve iktisadi vaziyetleri ve Türklerin Müslümanlara karşı mukavemetleri hakkında geniş bilgi için bkz. H.A.R. Gibb, The Arab Conquest in Central Asia, London 1923, s. 79-87.

64 Bu sırada İslam dünyasının genel durumu (mezhepler ve bölünme) hakkında bkz. M. Şemseddin Günaltay, "Selçuklular'ın Horasan’a İndikleri Zaman İslam Dünyasının Siyasal, Sosyal, Ekonomik ve Dinî Durumu", Belleten, VII/25, (1943), Ankara 1943, s. 59-99.

65 XI. yüzyılda Abbasi dünyasında hegemonya İranlılardan Türklere geçti [Şahruddîn Ebu'l Hasan Ali İbn Nâsır İbn Ali El-Hüseynî, Ahbârü'd-Devleti's-Selçukıyye, (nşr. N. Lügal), Ankara 1943, s. 1-2]. Bunlar Türkistan'dan gelen Türklerdi ve büyük çoğunlukla İslamiyet'i din olarak kabul ettiler (Barthold, Orta Asya Tarih ve Uygarlık, s. 28). Bunlardan Gazneliler, Sultan Mahmut (998-1030) öncülüğünde Afganistan'ın Gazne şehrini başkent olarak seçmişler ve buradan hareketle Hindistan'ın Pencap bölgesine çeşitli seferler düzenlemiş̧lerdi [N. Durak, Hindistan'a Kuzeyden Yapılan Seferler, Ankara 2000, s. 13-44; E. Merçil, Gazneliler Devleti Tarihi, Ankara 1989]. Dolayısıyla Hindistan'da ele geçirilen bu zenginlikler, Türkistan'a hâkim olma mücadelesinde Selçuklu ve Karahanlı devletlerine karşı kullanılmıştı. Fakat bunlar arasında hem Türk hem İslam hem de genel dünya tarihi açısından en önemli rolü oynayanlar hiç şüphesiz Selçuklulardı [O. Turan, Selçuklular Tarihi ve Türk İslam Medeniyeti, İstanbul 1980; M.A. Köymen, Büyük Selçuklu İmparatorluğu Tarihi I, Ankara 1979]. Nitekim ilk sultan Tuğrul Bey (10381063)'den itibaren Türkmenlere batı bölgeler bilahare de Anadolu yurt olarak işaret edilmiş [C. Cahen, “Türklerin Anadolu’ya İlk Girişi”,, (nşr. Y. Yücel-B. Yediyıldız), Belleten, LI/201, (Aralık 1987), Ankara 1987, s. 1380 vd.] ve Bizans ile Türk devleti arasındaki uçurum giderek daralmıştı. Bütün bu hadiseler önce Sultan Alp Arslan'ın 1071 Malazgirt Meydan Muharebesi [F. Sümer-Sevim Ali., İslam Kaynaklarına Göre Malazgirt Savaşı, Ankara 1988, s. 1 vd.] sonra da II. Kılıç Aslan'ın 1176 Miryokefalon (Kumdanlı) muharebesi ve Anadolu'nun artık kesin bir Türk yurdu olduğunun hukuki zeminde kabul edilmesiyle neticelendi [R. Grousset, A History of Asia, (nşr. D. Scott), Paris 1941, s. 69-70].

66 Gökalp, s. 7.

67 Ligeti, s. 22. 
özellikle Büyük Selçuklu Devleti'nin iktisadi politikası dikkate şayandır. ${ }^{68}$ Şehirlerin gelişmesine imkân veren ticaret hem Türklerin zenginleşmesine hem de batıda Buhara, Merv, Semerkant, Taşkent ve Harezm; ${ }^{69}$ doğuda, Kaşgar, Yarkent, Hotan ve Turfan gibi şehirlerin önemli kültür ve ticaret merkezleri haline gelmelerine zemin hazırlad1. ${ }^{70} \mathrm{Bu}$ arada, Harezmşah'ın Moğol ticaret kervanlarını kesmesi ve Türkistan ticaret yolunu kapamasıyla, ${ }^{71}$ Çingiz Han'ın Orta ve Batı Asya'ya seferlerine sebep olan ve bir dönüm noktası olarak ün yapan Otrar şehri de Ortaçağlarda Türkistan ticaretinde en önemli merkez görevini üstlenecektir. Zira geçmişte dünya ticaretinde çok önemli bir rolü olan bu şehir, bugün Türkistan'1 Sibirya ile ve gelecekte belki de Çin ile bağlayacak demiryollarının merkez noktası olmuştur. ${ }^{72}$

XII. yüzyılın sonları ile XIII. yüzyılın başlarında Hindistan ve Çin Hindistan’ı hariç bütün Asya ve Doğu Avrupa'yı ele geçirerek bu büyük coğrafyada ağırlıklı olarak yaşayan Türk ve Moğolları bir bayrak altında toplayan Temuçin ${ }^{73}$ Çingiz Han unvanıyla Moğol hükümdarı ilan edilmişti. ${ }^{74}$ Kısa sürede topraklarını genişleten Çingiz Han Türkistan'a ve dolayısıyla da İpek Yolu güzergâhlarına hâkim olma amacını gerçekleştirmek için ${ }^{75}$ önce Harezmşahlar Devleti

68 Selçuklu Devleti'nin iktisadi politikası ve bu amaçla kurulan Selçuk kervansarayları hakkında geniş bilgi için bkz. O. Turan, "Selçuk Kervansarayları", Belleten, X/39, (Temmuz 1946), Ankara 1946, s. 471496.

69 Göçebe kavimlerle yapılan ticaret Türkistan'ın diğer medenî vilayetleri için önemli olmakla beraber, coğrafî durumu itibarıyla Harezm için daha önemli idi. Bu bölgenin Türkleşmesi Barthold’a göre, XI. asır ile XIII. asır arasında yani burasının Selçuk Sultanlarına bağlı emirlerin idare ettikleri devirde gerçekleşmiştir. Nitekim Arap-Fars kaynaklarında, hem X. asırda Harezmlilerin kıyafet itibarıyla Türklere benzediği, hem de XIII. asırda Moğollar devrinde bile buranın dil bakımından tamamen Türk memleketi olarak tasvir edildiği kaydedilmiştir. Selçuklu emirleri Türk olmakla beraber, eski bir İran unvanı olan Harezmşah unvanını kullandılar. XI. Asrın son senelerinde burada Harezmşahlar sülalesi kuruldu ki, bunların hemen hepsinin isimleri Türkçe idi. Harezm bunların devrinde bu ülkenin bütün tarihinde ilk ve son defa olmak üzere pek büyük bir devletin merkezi olmuştur. Harezmşahlar önceleri Selçuk sultanlarının vekilleri iken, yavaş yavaş Müslüman âleminin doğu kısmının yüce hükümdarları sıfatını kazandılar. Hatta Selçuklu Devleti'nin çöküşünden sonra XII. Asır ortasında Bağdat Halifesinin vaktiyle kaybetmiş olduğu dünyevî hâkimiyeti geri almasını da kabul etmediler. Yani İslam memleketinde önceleri Selçuk Sultanlarının hakkı olan Sultan-ı İslam' lığın kendilerine geçtiğini iddia ettiler. Hatta son Harezmşahlar evvelce Selçuklular devrinde olduğu gibi hâkimiyetlerinin Bağdat'ta da kabul olunmasını istediler. Bkz., V.V. Barthold, Orta Asya Türk Tarihi, (nşr. Hüseyin Dağ), İstanbul 2011, s. 153-154.

70 V.V. Barthold, Tarihte Türk Dünyası, (nşr. M.A. Yalman, T. Andıç, N. Uğurlu), İstanbul 2008, s. 75-76.

71 Tarihte Otrar Faciası olarak addedilen ve hakkında dönemin kaynakları tarafından çeşitli rivayetler anlatılan ve neticede Harezmşah'ın ülkesinin Çingiz Han tarafından istila edilmesiyle sonuçlanan olaylar dizisi hakkında geniş bilgi için bkz. V.V. Barthold, Moğol İstilasına Kadar Türkistan, (nşr. H.D. Yıldız), Ankara 1990, s. 422-425.

72 A.Z. Velidi, “Türkistan'ın İktisadî Hayatı (Yerli-Rus Bakış Açıları ve Aris-Semey Hattı”, Türkistan'ın Bağımsızlı̆̆ına Hizmet Eden "Yeni Türkistan”dan Seçmeler (1927-1931), İstanbul 2005, s. 257.

73 Herbert M.J. Loewe, “The Mongols", The Cambridge Medieval History IV, (Ed. J.B. Bury- M.A.-F.B.A.), Cambridge 1923, s. 631; S. Şimşir, Dünden Bugüne Türkistan'da Türkler, İstanbul 2009, s. 157.

74 Bu bahis gizli tarihte uzun uzun anlatılır. Bkz. Moğolların Gizli Tarihi (Yazılışı 1240), (nşr. A. Temir), Ankara 1995, s. 43-125.

75 Cengiz Han, Moğolistan’daki dağınık Moğol kabilelerini itaati altına alarak Türkistan’a yönelince bu bölgedeki yollarda gerçekleşen ticaret karşısında adeta büyülenmişti. Tabi bu ticarette Uygurların çok önemli bir yeri vardı. Bundan dolayıdır ki onlara önemli resmi görevler vermiş ve hatta çocuklarına Uygurca öğretmek için onlardan öğretmen seçmişti. Dolayısıyla Uygurlara devlet vazifeleri verdikten sonra, zaten bölgedeki yolları ve ticari faaliyetleri çok iyi bilen Uygurlar için bu konuda başarısız olmaları düşünülemezdi. [R. Grousset, Conqueror of the World, (nşr. M. McKellar-D. Sinor), New York 1966, 
ile mücadeleye girerek Celâleddin Harezm Şah'1 mağlup edecek, ${ }^{76}$ sonra da 1220 yılı itibarıyla Maveraünnehir'i tamamen hâkimiyeti altına alacaktır. ${ }^{77}$ Arkasından da tekrar Tangut ve Güney Çin üzerine sefere çıkacaktı. ${ }^{78}$ Genel olarak Moğolların iletişim yollarına gösterdiği özenin, kendi silahlı kuvvetlerini bir yerden bir yere mümkün olduğunca çabuk göndermek, emirleri ulaştırmak ya da bilgi almak gereksiniminden kaynaklandığı görüşü bir tarafa, ${ }^{79}$ iletişim yolları söz konusu olduğunda bir kervanın yok edilmesinin ardından ilan edilen Harezm Savaşı'nın tek başına kanıtladığı üzere, en eski devirlerde olduğu gibi Çingiz döneminde de en büyük kaygının önemli geçit güzergâhlarını elde tutmak ve bu sayede iktisadi ihtiyaçlara cevap verebilmek olduğu görülmektedir. ${ }^{80}$

XIV. yüzyılın sonu ve XV. yüzy1l, Türkistan'da hiç görülememiş bir parlak devir olmuştur. Nitekim Timur ve sülalesinin İran ile Türkistan'1 yeniden birleştirmesinden sonra, ${ }^{81}$ Timur'un

s. 200-203]. Bu arada Moğollar zamanında İpek Yolu Şen-si'de (Şaanksi) Singan-fu'dan hareket eder, Lan-çu (Lanzhu), Kan-çu (Ganzu) ve Su-çu'dan geçerdi. Bu son şehirde Taklamakan Çölü’nü dönmek üzere yol ikiye ayrılırdı. Yer yer ender kuyularla bezenmiş zorlu bir bölgeden sonra kuzeyden Turfan, Kuça, Aksu ve Kaşgar'dan geçer, Hami'ye varırdı. Güneydense Lob-nor, Çer-çen, Hoten, Yarkent ve Kaşgar'a varmak için Altındağ'ı kat ederdi. Hoten ya da Kaşgar'da, Pencap'ta başlayıp Gilgit'ten geçen, Karakurum sıradağını kateden ve Çin Türkistan'ına varan, Hindistan'dan gelen zorlu ve sık sık karla kapanan bir yolla birleşirdi. Enlemesine bir yol da, Tarım'ın küçük kollarıyla yeterince sulanamayan 600 km'lik çöl üzerinden Aksu'yu Hoten'e bağlardı. İpek Yolu Kaşgar'da, güneyde Pamir ve Tanrı dağları arasından kayarak geldiği olağanüstü bir dağ kitlesiyle karşı karşıya gelirdi. Her bir 4400-4900 metreyi aşan yüksek geçitleri aşarak Hindistan'dan gelen ikinci bir yolla birleştiği Amuderya Vadisi'ne varırdı [J-Paul Roux, Moğol Imparatorluğu Tarihi, (nşr. A. Kazancıgil-A. Bereket), Aralık 2001, s. 453-454].

76 Cüveyni, Cengiz Han'ın Otrar üzerine yürümesinin sebebini, Han'ın, öldürülen tüccarların bizzat intikamlarını almak istemesi olarak gösterirken [Alâeddin Ata Melik Cüveyni, Tarih-i Cihân Güşâ, (nşr. M. Öztürk), Ankara 1998, s. 119] Cüzcâni, Celâleddin Harezm Şah'ın ordusunda yer alan çok sayıdaki yabancı unsurun (Karluk kabilesi olan İğrekler ve Harezmliler gibi) savaş sırasında ordudan ayrılıp başka yere gittiklerini ve Sultan'ın yalnızca Türklerle kaldığını nakleder [Cüzcâni-Raverty, Tabakât-ı Nâsırî, A General History of Mohammadan Dynasties of Asia II, (nşr. H.G. Raverty), Calcutta 1864, s. 1021].

77 Çingiz Han, İran ve Turan üzerine geldiğinde, bu yurtların padişahı Sultan Muhammed Harzmşah başkenti Ürgenç’i terk ederek Mâzenderan’a gitti. Çingiz Han, Buhara, Semerkant ve Taşkent’i alıp Irak, Gilân, Mazenderan, Azerbaycan ve Gürcistan'a, Cebe Noyan ve Sübedey Bahadır denilen iki üst düzey komutanıyla otuz bin kişilik bir askerî kuvvet gönderdi [Cahun, s. 180-182]. Ebu'l Gazi'nin kayıtlarına göre Çingiz'in batıya yönelmesi ve bu geniş toprakları ele geçirmesi çeşitli sebeplerle anlatılmıştır. Özellikle Harezmşah'ın başkenti, maiyet ve hazinenin bulunduğu Ürgenç'e büyük oğlu Cuci, ikinci oğlu Çağatay ve üçüncüsü olan Ögedey Han’ı takriben seksen bin kişiden müteşekkil büyük bir ordu ile gönderdi [Ebulgazi Bahadır Han, Şecere-i Terâkime (Türklerin Soykütüğ̈̈), (nşr. M. Ergin), Tercüman 1001 Temel Eser, s. 20/32].

78 Togan, Umumî Türk Tarihi'ne Giriş, s. 62.

79 J.P. Roux, Cengiz Han ve Moğol İmparatorluğu, İstanbul 2012, s. 28.

80 Aynı şekilde şunu da gözden uzak tutmamak gerekir ki, bu yollardan yalnızca asker, diplomat, yönetici ve tüccarlar geçmemiş, aynı zamanda misyoner ve serüvencilerin de geçtikleri unutulmamalıdır. Bkz. Roux, Moğol İmparatorluğu Tarihi, s. 450.

81 Timur'un İran ile Türkistan'ı birleştirmesi hadisesi Türk tarihi bakımından neticeleri itibarıyla çok önemlidir. Zira söz konusu bu birleşimden önce, Maveraünnehir-Kaşgar ve Yedisu-Doğu Tanrı Dağları arasında medenî mücadelelerin kuvvetli bir şekilde devam ettiğini görmekteyiz. XIII ile XIV. yüzyıllarda bu mücadele bir taraftan Kaşgar ve Maveraünnehir'de İran unsurlarıyla müttefik olan medeni Müslüman Türkler ve onlara dayanan beyler ve bazı hanlar, diğer taraftan Yedisu ve Uyguristan'daki Budist ve Hıristiyan Uygurlara ve Yedisuyun medeni gayrimüslim Türklerine dayanan göçebeler ile Çingiz oğullarının ekseriyeti arasında pek şiddetle devam etti. Dolayısıyla bu dönemde Türkistan'ın iki farklı kuvvet veya iki medeniyet cereyanı arasında çatıştı̆̆ına şahit olmaktayız. Bkz. Togan, Bugünkü Türkili 
ordusu daha uzaklara, batıda Bursa ve İzmir'e, güneydoğuda Dehli’ye ve kuzeyde İrtiş'e kadar gitti. ${ }^{82}$ Türkistan'ın jeopolitik öneminin farkında olan Timur'u Çingiz'den ayıran en önemli fark, Onun, ele geçirdiği şehirlerin imar işlerinde, tahribatında olduğu gibi büyük bir kararlılıkla çalışmasıyd1. ${ }^{83}$ Diğer taraftan ticaretin devlet hazinesi için en büyük gelir kaynağı olduğunun bilincinde olan Timur'un ${ }^{84}$ hem özellikle baharat ticaretine merkezlik teşkil eden Semerkand'1 başkent seçmesine, hem de devrin önemli ticaret yolları üzerinde yer alan şehirleri (Hoten gibi) ele geçirerek bütün Türkistan'a hâkim olma düşüncesine zemin hazırlad1. ${ }^{85}$ Çingiz Han'ın mirasının tekrar birleştirilmesine kadar büyük bir ihtirasa sahip olan Timur ${ }^{86}$ öldüğü zaman Çin'i inşa ettiği federasyona tekrar katmak üzere sefere çıkmış bulunuyordu. ${ }^{87}$

Oğul ve torunlar konusunda Çingiz Han kadar şanslı olmayan Timur'un ölümünden sonra imparatorluğun sınırlarının daha da genişletilesi bir yana, mevcut sınırların korunması bile söz konusu olmamış ve Timur'un halefleri kısa süre sonra İran'ın doğu ve güney eyaletleri dışında kalan tüm toprakları kaybettiler. ${ }^{88}$ Timur'dan sonra, Timurlular her ne kadar Doğu İran (Horasan), Maveraünnehir ve Batı İran'da tutunmayı başardı iseler de çeşitli Türkmen kabileleri (özellikle Kara ve Ak Koyunlular) arasında bir kısım mücadeleler başlayacaktı. Ancak bu Türkmenler, kendilerini Büyük Pers Hanedanlığı olarak addeden Safeviler karşısında ağır yenilgiler almaktan da kurtulamayacaklardı. Zira bu mücadelelerden önemli kazançlar sağlayan Safevi Şahları 1501-1756 yılları arasında kendi bölgelerinde bağımsız bir İran'1 yeniden inşa ederek Türkistan Jeopolitiği

(Türkistan) ve Yakın Tarihi I, s. 102.

82 Timur ve seferleri hakkında geniş bilgi için bkz., Şerefüddin Ali Yezdî, Emîr Timur (Zafernâme), (nşr. A. Batur), İstanbul 2013, s. 126 vd; İbn Arabşah, Acâibu'l-Makdur (Bozkırdan Gelen Bela), (nşr. A. Batur), İstanbul 2012, s. 31 vd; Nizamüddin Şâmî, Zafernâme, (nşr. Necati Lügal), Ankara 1987, s. 78 vd.

83 M. Fuat Köprülü- Barthold, W., İslâm Medeniyeti Tarihi, s. 85.

84 Timur'un tarihi hakkında baş menba olarak görülen biricik kronik, Yezd'li Giyâs ud-Din Ali'nin kroniğidir. Bu eserin tahlil ve tenkidi için bkz. W. Hinz, "Timuriler Tarihi Hakkında Menba Tetkiki”, (nşr. M.A. Köymen), Belleten, VI/21-22, (Nisan 1942), Ankara 1942, s. 85-120.

85 İ. Aka, “Timur Sadece Bir Asker mi İdi?”, Belleten, LXIV/20, Ankara 2001, s. 454.

86 Her ne kadar Timur, kendisini Çingiz Han'ın varisi sayarak bu yolda hareket etse de hakikatte Moğol hâkimiyeti yerine Türk hâkimiyeti, Çingiz İmparatorluğu yerine Timur İmparatorluğunu getiriyordu. Ancak Timur buna rağmen hukuken az çok hiçbir şey değiştirmemek iddiasındadır. Bu bakımdan mesela şeriat lehine Çingiz Yasak’ını kaldırdığını hiçbir zaman söylememesinden dolayı, zamanındaki bir kısım âlim tarafından Çingiz Han Yasak'ını Şeriata tercih ettiğinden dolayı fena Müslüman nazarıyla itham edilecektir. Fakat bu itham, Timur'un Orta Asya ahalisi önünde Çingiz Han muakkibi, yani yeni bir Çingiz Han gibi görünmeye ehemmiyet vermesinden dolayı tamamıyla şeklî bir noktayı nazara dayanmaktadır. Dolayısıyla uygulamada bunun aksi görünmekte ve harpleri sırasında Allah'a hamd etmekte ve Kur'an'dan yardım istemekteydi. [Bkz. R. Grousset, Stepler Imparatorluğu (Attila, Cengiz Han, Timur), (nşr. H. İnalcık), Ankara 2011, s. 413]. Bundan dolayı, Çingiz Han kaybolduktan sonra onun imparatorluğu, ekseriya zayıf hükümdarlar gelmekle beraber devam etmişti. Timur imparatorluğu ise Şahruh, Ulugbeg, Hüseyin Baykara, Babür gibi istidatlı hatta deha sahibi torunlara rağmen derhal ortadan kalkacak ve anayurdu küçük Maveraünnehir'de onun tabii Horasan'a münhasır kalacaktı. Timur Çingiz gibi attığını düşüren bir okçu, Çingiz gibi yenilmez bir cengâver ve Çingiz gibi zamanına hükmetmesine rağmen aralarında uçurum vardı. Bkz. Grousset, s. 413-414.

87 Grenard, bu hususta Timur'un Ahamenilerin ve Sasanilerin olduğu kadar Hulagû'nün da halefi olarak mütalaa edilmesi gerektiğini ifade ederek, İndus’tan Fırat'a kadar, imparatorluğu paylaşmış olan muhtelif hanedanları yok etmesini de bu şekilde açıklamaktadır. Bkz. Grenard, s. 56.

88 Fakat bu arada, bu dar saha içerisinde nispeten sükûnet sağlandığı ve askeri faaliyetler azaldığı için, Timur dönemine kıyasla daha canlı bir medeni gelişme yaşandığı hatırda tutulmalıdır. Bkz. Barthold, Orta Asya Tarih ve Uygarlık, s. 147-148. 
için önemli bir tehdit unsuru haline geldiler. ${ }^{89}$

XVI. yüzyılın ortalarında, 2 Ekim 1552'de Kazan Şehri ve Kazan Hanlı̆̆ı, 1557'lerin başlarında da Astrahan (Ejderhan) Hanlı̆̆ı'nın Rusya'nın eline geçmesiyle ${ }^{90}$ birincisiyle Orta İdil sahasında M.S. VI. yüzyıldan beri devam edegelen Türk hâkimiyetini sona ermiş ve ikincisiyle de takriben aynı yüzyıllardan itibaren muhtelif Türk kavimleri ve devletlerinin elinde bulunan, Bulgarlar ve Hazarlar zamanında olduğu gibi Altın Orda ve Kazan Hanlıkları devirlerinde dünya ticaretinin en işlek yollarından biri olan İdil-Volga nehri böylelikle Türklerden Ruslara geçmiş oluyordu. ${ }^{91}$ Dolayısıyla bu durum Rusların aynı zamanda Kuzey Kafkaslara ve daha sonra da Türkistan vilayetlerine doğru ilerleyişinin ilk adımını oluşturmaktaydı. ${ }^{92}$

XIX. yüzyılda Türkistan'1n Asya jeopolitiğinde adeta bir kalpgâh görevini üstlendiğini görmekteyiz. Nitekim Kırım Harbiyle (1853-1856) birlikte Balkanlara ve Anadolu'ya doğru Rus yayılışı durdurulduktan sonra, ${ }^{93}$ Rus istilacıları bu defa Türkistan'a yönelmişler ve Rus orduları General Skobeleff (1843-1882) komutasında Kafkaslardan Türkistan içlerine kadar inerek bu bölgelerdeki Türk ahaliye karşı adeta bir kıyım hareketi başlatmışlardı. ${ }^{94}$ Rusların Türkistan’a yönelmelerinde, İngilizlerin 1839'lu yıllara doğru güneyden yönelmeleri ve Rus ordularının 30 yıl gibi kısa bir sürede başarı elde etmelerinde ise onlara karşı mukavemet edebilecek kuvvetli bir

89 Nitekim ilk Safevi hükümdarı Şah İsmail (1501-1524), Batı İran'da hâkimiyetini sağlamlaştırdıktan sonra Türkmen göçebeleri üzerine yürümüş ve onlara ağır tahribatlar vermişti. Maveraünnehir (Buhara ve Semerkand)'de ve Horasan'da diğer Türkmenleri bünyelerinde barındıran Özbekler, Timurluların son torunlarından olup ağırlıklı olarak Sünni idiler. Dolayısıyla Şiilik propagandası yaparak hareket eden Şah İsmail, ilk önce bunlar üzerine yürüyerek 1510'da Horasan'ı ele geçirecek, arkasından da bunları tekrar Maveraünnehir'de; bundan sonra yaşayacakları kendilerini sınırlayan yere sürdü. Fakat bu kez de batıda yine Sünni inancına sahip başka bir Türk devletiyle karşılaştılar: Osmanlı Devleti. Bkz. Grousset, A History of Asia, s. 94-95.

90 Rusya, en erken zamanlardan beri Ural-Altay mıntıkalarında yer alan topluluklarla temas içerisinde olmuştur. Bu durum özellikle onun coğrafî pozisyonuna atfedilir. Tabi söz konusu bu temas her zaman dostane şekillerde olmamış, fakat zaman zaman dini, sosyal ve politik meselelerde çatışmaların da yaşandığı görülmektedir. Orta çağlarda her ne kadar bir Rus medeniyetinden bahsedilemese de onların tarih sahnesinde yer aldıkları zamanlardan itibaren Hıristiyan prensipleri üzerinde kurulmuş bir Rus devlet geleneğinin oluştuğunu kabul etmeliyiz. Dolayısıyla Rusya İslam’a da bir antipati beslerken, bunu Hıristiyan dünyasının bir öncüsü olarak yürütmekteydi. Ancak çoğu zaman da Rusya’nın Türk ve Moğol göçebelerinin baskıları karşısında boyun eğmekten başka bir çaresi de yoktu. Yani, Rusya’nın bağımsız olma sürecinde politik ya da sosyal anlamda Asya göçerlerinin etkilerine maruz kaldığı pek çok seçkin alim tarafından ileri sürülmektedir [Vambéry, s. 7]. Ruslar Kazan muhasarasında başlangıçta başarılı olamamışlar ve Türkü Türke kırdırmak için türlü hilelere başvurmuşlardı. Öyle ki Rusların bu ağır saldırıları karşısında Kırım Türkleri arasında çeşitli destanlar ve efsaneler ortaya çıkmış̧ır. Mesela bunlardan Kırımlı bir kahraman olan Çora Batır destanı için bkz., G. Çandarlıoğlu, "Çora Batır”, Türk Dünyası Tarih Dergisi, I/1, (15 Ocak 1987), İstanbul 1987, s. 2-3.

91 A.N. Kurat, Rusya Tarihi (Başlangıçtan 1917’ye Kadar), Ankara 1993, s. 152-154.

92 Kurat, s. 155.

93 Kurat, s. 346.

941868 yılında Türkistan’a gönderilen General Skobeleff'in emrindeki Rus ordularının bölgede savaştan ziyada bir yok etme veya daha doğrusu topluca imha etme harekâtı için bkz. J.K. Goodrich, Russia in Europe and Asia, Chicago 1912, s. 204-212. 
Türk devletinin bulunmayıșı temel sebep olarak temayüz etmektedir. ${ }^{95}$

\section{Sonuç}

Asya kıtasının merkezî bölgelerini de içine alıp Hazar Denizi’nden Kadırgan Dağları'na kadar uzanan toprakları ihtiva eden Türkistan kıtanın kalp-gâhı durumundadır. Bu özelliği ona Asya jeopolitiğinde ayrı bir önem kazandırmış dolayısıyla mutlaka hâkim olunması gerektiği düşüncesini ortaya çıkarmıştır. Bu coğrafya Çin'den Ön Asya’ya ya açılan pek çok tarihi yola sahip olduğu gibi Doğu Avrupa'yı Hindistan'a bağlayan stratejik ulaşım noktalarına da hâkimdir. Dolayısıyla geçmişte muhtelif hâkimiyetler Türkistan’ın sahip olduğu jeopolitik konumunu iyi analiz etmişler ve bu stratejik kilit noktalarına hâkim olmak amacıyla amansız mücadelelere girişmişlerdir.

Diğer taraftan tarihî İpek Yolu'nun açılması ve önem kazanmasında birbirinden farklı iddialar olmakla birlikte Büyük İskender'in doğu yönünde giriştiği seferlerin de etkili olduğunu kabul edersek M.Ö. II. yüzyıldan itibaren Çin ipeğinin Greko-Roma dünyasına ihraç edilmesiyle başlayan ticarî canlılık ana kervan yolunun merkezindeki Türkistan'a ayrı bir stratejik önem kazandırmıştır. O dönemde Avrupa'da kullanılmaya başlanan ipeğe duyulan ihtiyaç öylesine fazlaydı ki Aristokratlar ve saray mensupları arasında döviz birimi olarak kullanılıyordu, hatta savaşa katılan askerlere ücret olarak ipek veriliyordu. Doğu dünyasının zenginleşmesine vesile olan söz konusu ticaretten Türkistan'a hâkim olan devletler tabii olarak istifade ediyorlardı. Çünkü hâkimiyetlerini sağlamlaştırmak ve uzak bölgelere hükmedebilmek hatta yeni güç ve iktidar alanları açabilmek için gereken orduyu besleyebilmek her şeyden önce maddi imkânlara bağlıydı. Ticaretin devlet hazinesi için en büyük gelir kaynağı olduğunun bilincinde olan gerek Türk gerekse Çin, İran ve Bizans gibi yabancı devletler ticaret yollarını veya onlara yakın yerlerdeki şehirleri kontrolleri altında tutmaya çalışmışlardır. Tarih sayfalarında aktörler değişse de jeopolitiğin pek değişmediğine tanık olmaktayız.

95 Nitekim bu dönemde Türkistan'ın Türk ahalisi Kazak, Kırgız, Özbek, Karakalpak, Türkmen kavimleri (veya uruğları) birbirleriyle mücadele ederek, zaafa düşmüşlerdi. Türkistan Türklerinin mühim bir kısmı (Kazaklar ve Kırgızlar) göçebe olmakla, modern Rus teşkilatına karşı durabilecek durumda değillerdi. Türkistan'ın yerleşik Türk ahalisi ise, dinî taassup, Orta çağlardan kalma teşkilatı ve basiretsiz emirlerinin idaresinde uzun zaman kalmakla adeta yaşama kudretini kaybetmiş gibiydiler. Bkz. Kurat, s. 352-353. 


\section{Kaynakça}

Aka, İ., “Timur Sadece Bir Asker mi İdi?”, Belleten, LXIV/20, Ankara 2001,

Alâeddin Ata Melik Cüveyni, Tarih-i Cihân Güşâ, (nşr. M. Öztürk), Ankara 1998,

Barthold, V.V., Orta Asya Tarih ve Uygarlı, (Rusçadan çev. A. Batur), İstanbul 2010,

Barthold, V.V., Tarihte Türk Dünyası, (nşr. M.A. Yalman, T. Andıç, N.Uğurlu), İstanbul 2008 ,

Barthold, VV., Moğol İstilasına Kadar Türkistan, (nşr. H.D. Yıldız), Ankara 1990,

Barthold, W., Türk-Moğol Ulusları Tarihi, (nşr. H. Eren), Ankara 2006,

Cahen, C., “Türklerin Anadolu’ya İlk Girişiı”, (nrş. Y. Yücel-B. Yediyıldız), Belleten, LI/201, (Aralik 1987), Ankara 1987, s. 1380-1397.

Cahun, L., Asya Tarihine Giriş (Kökenlerden 1405 'e, Türkler ve Moğollar), (nşr. S. İ. Kaya), İstanbul 2006,

Church, P.W., Chinese Turkestan, London 1901,

Cramer, J.A., A Geographical and Historical Description of Asia Minor, Oxford 1961,

Cüzcâni-Raverty, Tabakât-ı Nâsırî, A General History of Mohammadan Dynasties of Asia II, (nşr. H.G. Raverty), Calcutta 1864,

Çandarlığlu, G., “Çora Batır”, Türk Dünyası Tarih Dergisi, I/1, (15 Ocak 1987), İstanbul 1987, s. 2-4.

Devellioğlu, F., Osmanlıca-Türkçe Ansiklopedik Lügat, Ankara 2003,

Durak, N., Hindistan 'a Kuzeyden Yapılan Seferler, (Basılmamış Doktora Tezi), Ankara 2000,

Durmuş, İ., Ískitler (Sakalar), Ankara 2008,

Ergin, M., Orhun Abideleri, İstanbul 2006,

Gabain, A. Von, "Köktürklerin Tarihine Bir Bakış", D.T.C.F.D., C.II, S.V, Ankara 1943, s.685-695.

Gibb, H.A.R., The Arab Conquest in Central Asia, London 1923,

Giles, P., "The Aryans", The Cambridge History of India I, Ancient India, (nşr. E.İ. Rapson), Delhi 1955, s. 52-77.

Goodrich, J.K., Russia in Europe and Asia, Chicago 1912,

Gökalp, C., Kaynaklara Göre Orta Asya 'nın Önemli Ticari ve Askeri Yolları (M.S.552-999), Ankara 1973,

Gömeç, S., Kök Türk Tarihi, Ankara 2003,

Grenard, F., Asya'nın Yükselişi ve Düşüşü, (nşr. O. Yüksel), İstanbul 1992,

Grousset, R., A History of Asia, (nşr. D. Scott), Paris 1941,

Grousset, R., Conqueror of the World, (nşr. M. McKellar-D.Sinor), New York 1966, 

2011 ,

Grousset, R., Stepler Imparatorluğu (Attila, Cengiz Han, Timur), (nşr. H. İnalc1k), Ankara

Gumilev, L.N., Eski Türkler, (nşr. A. Batur), İstanbul 2011,

Günaltay, M. Şemseddin, “Selçuklular'ın Horasan'a İndikleri Zaman İslam Dünyasının Siyasal, Sosyal, Ekonomik ve Dinî Durumu”, Belleten, VII/25, (1943), Ankara 1943, s. 59-99.

Helfen, O. Maenchen, “Archaistic Names of the Hiung-nu”, The Central Asiatic Journal, 6/I, Wiesbaden 1961, s. 249-260.

Hinz, W., “Timuriler Tarihi Hakkında Menba Tetkiki”, (nşr. M.A. Köymen), Belleten, VI/2122, (Nisan 1942), Ankara 1942, s.85-120.

İbn Arabşah, Acâibu'l-Makdur (Bozkırdan Gelen Bela), (nşr. A. Batur), İstanbul 2012,

Juping, Y., "Alexander the Great and the Emergence of the Silk Road", The Silk Road, V.6.,No.3 (Winter-Spring 2009), (nşr. D.C. Waugh), Washington 2009, s.15-38.

Kafesoğlu, İ., Türk Milli Kültürü, İstanbul 2005,

Kafesoğlu, İ., Türk-İslam Sentezi, İstanbul 2008,

Karatay, O., Iran ile Turan (Hayali Milletler Çă̆ında Avrasya ve Ortadoğu), Ankara 2003,

Köprülü, M. Fuat - Barthold, W., İslâm Medeniyeti Tarihi, Ankara 2004,

Köymen, M.A., Büyük Selçuklu İmparatorluğu Tarihi I, Ankara 1979,

Kurat, A.N., "Doğu Avrupa Türk Kavim ve Devletleri”, Türk Dünyası El Kitabı I, (CoğrafyaTarih), I-A-23, Ankara 1992, s. 175-186.

Kurat, A.N., Rusya Tarihi (Başlangıçtan 1917'ye Kadar), Ankara 1993,

Ligeti, L., Bilinmeyen İç Asya, (nşr. S. Karatay), Ankara 1986,

Little, A., The Far East, Oxford 1905,

Loewe, Herbert M.J., "The Mongols", The Cambridge Medieval History IV, (Ed. J.B.BuryM.A.-F.B.A.), Cambridge 1923,

Lyde, L.W., A Geography of Asia, London 1907,

Merçil, E., Gazneliler Devleti Tarihi, Ankara 1989,

Mesudî, Murûc ez-Zeheb (Altın Bozkırlar), (nşr. A Batur), İstanbul 2004,

Moğolların Gizli Tarihi (Yazılışı 1240), (nşr. A. Temir), Ankara 1995,

Nizamüddin Şâmî, Zafernâme, (nşr. Necati Lügal), Ankara 1987,

Ögel, B., "Eski Orta Asya Kabileleri Hakkında Araştırmalar I: Yüe-çi’ler” AÜDTCF Dergisi, XV/1-3, (Mart-Haziran-Eylül 1957), Ankara 1957, s. 247-255.

Ögel, B., Íslamiyet’ten Önce Türk Kültür Tarihi (Orta Asya Kaynak ve Buluntularına Göre), Ankara 1988,

Rapson, E.J., "Scythian and Partian Invaders", The Cambridge History of India I, (nşr. E.J. Rapson), Dehli 1955, s. 508-529. 
Rasonyi, L., Tarihte Türklük, Ankara 1996,

Reclus, E., The Earth and Its İnhabitants ASİA I, (nşr. A.H. Keane), New York 1891,

Reynolds, J.B., Regional Geography Asia, London 1908,

Roux, J-P., Moğol İmparatorluğu Tarihi, (nşr. A. Kazancıgil-A.Bereket), Aralık 2001,

Sevim, Ali,-F. Sümer, İslam Kaynaklarına Göre Malazgirt Savaşı, Ankara 1988,

Sinor, D., "İç Asya Kavramı”, Erken İç Asya Tarihi, (nşr. D. Sinor), İstanbul 2000,

Skrine, F.H. -Ross, E.Denison., The Heart of Asia (A History of Russian Turkestan and the Central Asian Khanates from the Earliest Times), London 1899,

Smith, V. A., "The Kushan, or Indo-Scythian, Period of Indian History (B.C. 165 to A.D. 320)", JRAS, (1903), London 1903, s. 1-64.

Spuler, B., “Amû-Daryâ", Ė்/I., Leiden 1986, s.454-457

Strange, G.Le., The Lands of the Eastern Caliphate (Mesopotamia, Persia, and Central Asia from the Moslem Conquest to the time of Timur), New York 1873,

Sümer, F., “Altay Dağları”, Türk Dünyası Tarih Dergisi, I/1, (15 Ocak 1987), İstanbul 1987 , s. 32-53.

Şahruddîn Ebu'l Hasan Ali İbn Nâsır İbn Ali El-Hüseynî, Ahbârü'd-Devleti's-Selçukryye, (nşr. N. Lügal), Ankara 1943,

Şerefüddin Ali Yezdî, Emîr Timur (Zafernâme), (nşr. A. Batur), İstanbul 2013,

Şimşir, S., Dünden Bugüne Türkistan'da Türkler, İstanbul 2009,

Taberî, Milletler ve Hükümdarlar Tarihi I-II, (nşr. Z. Kadirî Ugan-A. Temir), İstanbul 1992 ,

Tenney, C.D., Geography of Asia, London 1904,

Togan, A.Z.V., “Türkistan İsmi Sınırları ve Yüzölçümü Hakkında”, Türkistan’ın Bă̆ımsızlı̆̆ına Hizmet Eden “Yeni Türkistan”dan Seçmeler (1927-1931), İstanbul 2005, s. 25-43,

Togan, A.Z.V., “Türkistan'ın İktisadî Hayatı (Yerli-Rus Bakış Açıları ve Aris-Semey Hattı”, Türkistan'ın Bă̆ımsızlı̆̆ına Hizmet Eden “Yeni Türkistan”dan Seçmeler (1927-1931), İstanbul 2005, s.257-269.

Togan, A.Z.V., Bugünkü Türkili (Türkistan) ve Yakın Tarihi I (Batı ve Kuzey Türkistan), İstanbul 1981,

Togan, A.Z.V., Umumî Türk Tarihi’ne Giriş, İstanbul 1981,

Turan, O., "Selçuk Kervansarayları", Belleten, C.X/S.39, (Temmuz 1946), Ankara 1946, s. 471-496.

Turan, O., Selçuklular Tarihi ve Türk Íslam Medeniyeti, İstanbul 1980,

Vambéry, A., Western Culture in Eastern Lands, London 1906,

Walker, J.T., "Tibet”, Asia, (nşr. A.J. Herbertson), London 1903, s.105-127.

Yiğit, A., Türk Ülkeleri ve Türklerin Yaşadıkları Bölgelerin Coğrafyası, Elâzı̆̆ 2000, 